\title{
$N$-Acetylcysteine (NAC): Impacts on Human Health
}

\author{
Micaely Cristina dos Santos Tenório ${ }^{1}$, Nayara Gomes Graciliano ${ }^{2} \oplus$, Fabiana Andréa Moura ${ }^{3,4}$, \\ Alane Cabral Menezes de Oliveira ${ }^{2,3}$ and Marília Oliveira Fonseca Goulart 1,2,*(D) \\ 1 Institute of Chemistry and Biotechnology, Federal University of Alagoas, Maceió 57072-970, Alagoas, Brazil; \\ micaely.tenorio@hotmail.com \\ 2 Institute of Biological and Health Sciences, Federal University of Alagoas, Maceió 57072-970, Alagoas, Brazil; \\ nayaragraciliano@hotmail.com (N.G.G.); alanecabral@gmail.com (A.C.M.d.O.) \\ 3 College of Nutrition, Federal University of Alagoas, Maceió 57072-970, Alagoas, Brazil; \\ fabiana.moura@fanut.ufal.br \\ 4 College of Medicine, Federal University of Alagoas, Maceió 57072-970, Alagoas, Brazil \\ * Correspondence: mofg@qui.ufal.br or mariliaofg@gmail.com; Tel.: +55-829-8818-0463
}

Citation: Tenório, M.C.d.S.; Graciliano, N.G.; Moura, F.A.; Oliveira, A.C.M.d.; Goulart, M.O.F. $\mathrm{N}$-Acetylcysteine (NAC): Impacts on Human Health. Antioxidants 2021, 10, 967. https://doi.org/10.3390/ antiox10060967

Academic Editors: Maria A. Livrea and Mario Allegra

Received: 25 May 2021

Accepted: 14 June 2021

Published: 16 June 2021

Publisher's Note: MDPI stays neutral with regard to jurisdictional claims in published maps and institutional affiliations.

Copyright: (C) 2021 by the authors Licensee MDPI, Basel, Switzerland. This article is an open access article distributed under the terms and conditions of the Creative Commons Attribution (CC BY) license (https:// creativecommons.org/licenses/by/ $4.0 /)$.

\begin{abstract}
N$-acetylcysteine (NAC) is a medicine widely used to treat paracetamol overdose and as a mucolytic compound. It has a well-established safety profile, and its toxicity is uncommon and dependent on the route of administration and high dosages. Its remarkable antioxidant and anti-inflammatory capacity is the biochemical basis used to treat several diseases related to oxidative stress and inflammation. The primary role of NAC as an antioxidant stems from its ability to increase the intracellular concentration of glutathione (GSH), which is the most crucial biothiol responsible for cellular redox imbalance. As an anti-inflammatory compound, NAC can reduce levels of tumor necrosis factor-alpha (TNF- $\alpha$ ) and interleukins (IL- 6 and IL-1 $\beta$ ) by suppressing the activity of nuclear factor kappa B (NF- $\mathrm{B}$ ). Despite NAC's relevant therapeutic potential, in several experimental studies, its effectiveness in clinical trials, addressing different pathological conditions, is still limited. Thus, the purpose of this chapter is to provide an overview of the medicinal effects and applications of NAC to human health based on current therapeutic evidence.
\end{abstract}

Keywords: $\mathrm{N}$-acetylcysteine; mechanism of action; antioxidant; anti-inflammatory

\section{Introduction}

$N$-Acetylcysteine (NAC) is a drug approved by the Food and Drug Administration (FDA) and recognized by the World Health Organization (WHO) as an essential drug, widely used for the treatment of acetaminophen overdose (paracetamol) and more recently as a mucolytic agent, in respiratory diseases [1]. In some countries, including the United States, Canada, and Australia, NAC is commonly available as an over-the-counter nutritional supplement, with antioxidant properties and great commercial appeal as a nutraceutical [2].

The primary role of NAC is associated with its antioxidant and anti-inflammatory activity, which favors the maintenance of a cellular redox imbalance. For this reason, its therapeutic potential concerns a series of diseases that link oxidative stress to its etiology and progression [3,4]. However, the mechanisms via which NAC exerts its antioxidant and cytoprotective capacity in different physiological conditions have not yet been fully clarified [5]. The growing interest in investigating the favorable effects of NAC involves not only its action as a potent cell bio-protector but also its pharmacokinetic characteristics, related to safety, absorption, and bioavailability, associated with its low cost $[3,4]$.

Animal studies have shown that NAC exerts a potent protective effect against oxidative stress and inflammation under different conditions, including improvement of brain damage induced by transient cerebral ischemia [6], pain and inflammation management in case of infection [7], and restoration of thyroid morphology via reduced infiltration of inflammatory cells [8]. Although several in vivo and ex vivo studies have shown that NAC plays important 
biological actions that can potentially support its putative therapeutic roles, its effectiveness in clinical studies in addressing different pathological conditions still has conflicting results $[4,9]$. Thus, the purpose of this review is to provide an overview of the medical effects and applications of NAC to human health based on current therapeutic evidence.

\section{Pharmacokinetics and Bioavailability}

NAC can be administered orally, intravenously, or by inhalation, being commonly safe and well tolerated, even in high doses [10]. Orally, it suffers rapid intestinal absorption and metabolism by the liver, which directs most of the cysteine released toward GSH synthesis [11]. After oral administration, its maximum plasma concentration $\left(C_{\max }\right)$ occurs approximately between 1 and $2 \mathrm{~h}$ [12].

The bioavailability of free NAC is very low $(<10 \%)$, and only a tiny amount of the intact molecule reaches the plasma and tissues $[13,14]$. Additionally, due to the variety of ways that NAC can be found in plasma (oxidized, reduced, and bound to proteins), its pharmacokinetics (PK) is not yet fully understood $[15,16]$. NAC can be oxidized to a disulfide, $N, N^{\prime}$-diacetylcystine, and it still generates mixed disulfides via a reaction with other low-molecular-weight thiols. After their complete metabolism, cysteine, cystine, inorganic sulfate, and glutathione are the primary metabolic products produced [14].

Due to the absence of the first-pass intestinal and hepatic metabolism, intravenous administration allows rapid delivery of high concentrations of NAC, being the route used for the treatment of paracetamol overdose [16]. After administering intravenous NAC at a dosage of $150 \mathrm{mg} / \mathrm{kg}$ over $15 \mathrm{~min}$, the $C_{\max } \mathrm{NAC}$ was on average $554 \mathrm{mg} / \mathrm{L}$ [17]. The volume of distribution $(\mathrm{Vd})$ of the total NAC ranges from 0.33 to $0.47 \mathrm{~L} / \mathrm{kg}[13,14]$.

According to the study by Olsson et al. (1988) [14], after the administration of intravenous NAC (200 mg diluted 1:10 in 0.9\% saline), covalent binding to proteins was significant after $60 \mathrm{~min}$. It increased over time to reach a maximum of $50 \%, 4 \mathrm{~h}$ after the dose, decreasing again to approximately $20 \%$ after $12 \mathrm{~h}$. For total NAC, the terminal half-life was $5.58 \mathrm{~h}$ after intravenous administration and $6.25 \mathrm{~h}$ after oral administration of $400 \mathrm{mg}$. Oral bioavailability was $4.0 \%$ and $9.1 \%$ for reduced and total NAC, respectively.

In patients with severe liver injury, PK appears to be altered due to less clearance. In the study by Jones et al. (1997) [15], the PK of NAC was evaluated in patients with chronic liver disease versus control. After administering a $600 \mathrm{mg}$ dose of intravenous NAC over $3 \mathrm{~min}$, the area under the serum concentration versus time curve was almost double for cirrhotic patients ( 152.3 vs. $93.9 \mathrm{mg} / \mathrm{L} / \mathrm{h}$ ) compared to healthy controls. Similarly, patients with end-stage renal disease (ESRD) and normal liver function also have lower total NAC clearance when compared to healthy individuals [18].

The study by Nolin et al. (2010) [18] evaluated the PK of NAC after oral administration of multiple doses (600 mg and $1200 \mathrm{mg}$ of NAC every $12 \mathrm{~h}$ ) to patients with ERSD versus healthy controls (600 mg every $12 \mathrm{~h}$ ) for a period of 14 days. Significant dose-related increases in $C_{\max }$ and plasma concentration-time curve values were observed in patients with ERSD at different dosages, with no change in total clearance. Between patients with ERSD and healthy controls, there were significant PK differences. The full clearance of $600 \mathrm{mg}$ of oral NAC in subjects with ESRD was $4.9 \pm 3.5 \mathrm{~L} / \mathrm{h}$ versus $56.1 \pm 12.7 \mathrm{~L} / \mathrm{h}$ in healthy subjects. Thus, the total clearance of NAC was reduced by $90 \%$ in patients with ERSD, with a half-life 13 times greater $(51.3 \pm 36.7 \mathrm{~h}$ versus $3.7 \pm 0.8 \mathrm{~h}$ control) and, consequently, greater systemic exposure in these individuals.

The concomitant use of NAC orally with activated charcoal can reduce the bioavailability of NAC by impairing its absorption. However, the results are still controversial [16]. The elimination of NAC occurs through the renal system, in which about $30 \%(27.0 \pm 12.8)$ is excreted in the urine [10] and only 3\% is excreted in the feces [19]. Oral administration of $100 \mathrm{mg}$ of ${ }^{35}$ S-labeled NAC to patients with respiratory disorders showed renal excretion of approximately $22 \%$ of radioactivity through urine (range 13-38\%) after $24 \mathrm{~h} \mathrm{[20].} \mathrm{A}$ more recent study showed the range of urinary excretion of Chinese (3.66\%) and Caucasian $(3.80 \%)$ subjects after $600 \mathrm{mg}$ of oral NAC administration. All research participants were 
healthy. According to the authors, the reduced elimination range found in the study was consistent with the extensive metabolism and transformation that NAC undergoes after its administration [21].

The adverse effects of NAC vary from mild to severe and depend on the formulation and dosage used, but an extensive review of multicentric medical records has shown that intravenous and oral NAC is associated with minimal side-effects. In oral administration, the most common adverse effects are gastrointestinal symptoms such as nausea and vomiting, which occur in up to $23 \%$ of patients [22]. Other reactions include itching and erythema [11]. The pungent smell of NAC, which resembles rotten eggs (due to sulfur), also contributes to manifestations of nausea and vomiting after oral administration. NAC is commonly diluted in caffeine-free diet sodas to mask the smell and taste and to facilitate acceptance. Effervescent flavored tablets already exist as a new formulation of NAC [23]. Intravenous administration can also cause symptoms such as nausea and vomiting, with a frequency of up to $9 \%$ [22].

Considering the formulation, intravenous administration usually causes a more significant proportion of adverse effects when compared to oral administration, especially after the infusion of the initial load, which releases a high plasma concentration of NAC [11]. More serious adverse effects, such as anaphylactoid reactions, are uncommon and more remarkable in up to $8.2 \%$ of patients. Anaphylactoid reactions involve a response of nonimmunological origin, probably related to the release of non-IgE-mediated histamine. They include cutaneous symptoms, such as flushing, itching, and angioedema, and systemic symptoms, such as bronchospasm and hypotension. The manifestations of cutaneous symptoms in anaphylactoid reactions are usually greater, with a frequency of $75 \%$ [24].

The inhaled form of NAC is most commonly used to treat respiratory diseases. In general, studies with inhaled NAC demonstrated a safety profile similar to other formulations, demonstrating good tolerance to this type of formulation [25-27]. Adverse symptoms after administration of inhaled NAC include bacterial pneumonia, cough, sore throat, and drug-induced pneumonitis, among which coughing is the most common [27]. A systematic review with meta-analysis showed that the incidence of adverse effects was significantly higher in the treatment with inhaled NAC when compared to oral NAC; however, the study did not identify any significant difference in the incidence of adverse effects between NAC therapy and the treatments of control [28].

The toxicity of NAC overdose has not yet been defined for patients with paracetamol overdose or for healthy people using single or repeated doses of NAC [29]. It has been reported that an overdose of NAC $(100 \mathrm{~g})$ in a short time can cause hemolysis, thrombocytopenia, acute renal failure, and death in patients with glucose-6-phosphate dehydrogenase (G6PD) normal. The reported case resulted from an error during the administration of the loading dose of NAC for the treatment of paracetamol overdose, which should be $10 \mathrm{~g}$ $(10,000 \mathrm{mg})$ [30]. Toxicity data for NAC in animals are available [29]. Box 1 provides a summary of the main characteristics of NAC. 
Box 1. Summary of the compound $N$-acetylcysteine.

\begin{tabular}{|c|c|c|c|}
\hline \multicolumn{4}{|c|}{ Summary of the Compound $N$-Acetylcysteine } \\
\hline \multicolumn{4}{|c|}{$\begin{array}{c}\text { Drug indication } \\
\text { NAC is used mainly as a mucolytic and in the management of acetamin }\end{array}$} \\
\hline \multirow[t]{3}{*}{ Chemical structure } & \multirow{2}{*}{\multicolumn{2}{|c|}{$\begin{array}{l}\text { Molecular formula } \\
\qquad \mathrm{C}_{5} \mathrm{H}_{9} \mathrm{NO}_{3} \mathrm{~S}\end{array}$}} & Synonyms \\
\hline & & & \multirow{2}{*}{$\begin{array}{ll}\text {. } & \text { N-Acetyl-cysteine; } \\
\text {. } & \text { Acetylcysteine; } \\
\text {. } & \text { N-Acetylcysteine; } \\
\text {. } & \text { NAC; } \\
\text { - } & \text { Ac-Cys-OH; } \\
\text {. } & 616-91-1 .\end{array}$} \\
\hline & & & \\
\hline $\begin{array}{l}\text { Molecular weight } \\
163.2 \mathrm{~g} / \mathrm{mol}\end{array}$ & \multicolumn{2}{|c|}{$\begin{array}{l}\text { Protein binding } \\
\quad 66-97 \% \\
\text { (usually to albumin) }\end{array}$} & $\begin{array}{l}\text { WHO essential medicines } \\
\text { Antidotes and other } \\
\text { substances used in } \\
\text { poisonings. }\end{array}$ \\
\hline \multirow{3}{*}{$\begin{array}{l}\quad \text { Drug classes } \\
\text { - } \quad \text { Antidotes; } \\
\text { Toxicological } \\
\text { emergency. }\end{array}$} & \multirow{3}{*}{\multicolumn{2}{|c|}{$\begin{array}{ll}\text { - } & \text { Antiviral agents; } \\
\text { - } & \text { Expectorants; } \\
\text { Free-radical scav }\end{array}$}} & $\begin{array}{c}\text { Taste } \\
\text { Characteristic sour taste }\end{array}$ \\
\hline & & & $\begin{array}{c}\text { Color/Form } \\
\text { White crystalline powder }\end{array}$ \\
\hline & & & $\begin{array}{c}\text { Odor } \\
\text { Slight acetic odor }\end{array}$ \\
\hline \\
\hline \multicolumn{4}{|c|}{$\begin{array}{l}\text { - } \quad \text { Anaphylactoid reactions, such as rash, hypotension, wheezing, and/or dyspnea, have been reported after administration of } \\
\text { parenteral NAC; } \\
\text { - } \quad \text { Anaphylactoid reactions can be more severe and even cause death in patients with asthma; } \\
\text { - } \quad \text { Skin rash, urticaria, and pruritus are the most reported adverse effects after intravenous NAC administration; } \\
\text { - } \quad \text { Acute flushing and erythema are less serious adverse reactions after intravenous administration of NAC; } \\
\text { - } \quad \text { Chest tightness and bronchoconstriction have been reported after the use of NAC; } \\
\text { - } \quad \text { Increased airway obstruction can occur after oral NAC inhalation; } \\
\text { - } \quad \text { Gastrointestinal symptoms, including nausea and vomiting, are more frequent and may occur after oral administration of NAC. }\end{array}$} \\
\hline \\
\hline \multicolumn{4}{|c|}{$\begin{array}{l}\text { Absorption } \\
\text { Bioavailability is } 6-10 \% \text { following oral administration and less than } 3 \% \text { following topical administration; } \\
\text { Serum concentrations after intravenous administration of an initial loading dose of } 150 \mathrm{mg} / \mathrm{kg} \text { over } 15 \mathrm{~min} \text { are about } \\
500 \mathrm{mg} / \mathrm{L} \text {. }\end{array}$} \\
\hline \multicolumn{4}{|c|}{ Metabolism } \\
\hline \multicolumn{4}{|c|}{$\begin{array}{l}\text { Deacetylated by the liver to cysteine and subsequently metabolized; } \\
\text { After oral inhalation or intratracheal instillation, most of the administered drug appears to participate in the sulfhydryl } \\
\text { disulfide reaction, while the rest is absorbed by the pulmonary epithelium, deacetylated by the liver to cysteine to } \\
\text { be metabolized. }\end{array}$} \\
\hline $\begin{array}{l}\text { Half-life } \\
\text { Adults-5.6 h; } \\
\text {. } \quad \text { Neonates-11 h. }\end{array}$ & $\begin{array}{c}\text { Clearance } \\
0.11 \mathrm{~L} / \mathrm{h} / \mathrm{kg}\end{array}$ & $\begin{array}{c}\text { Volume of distrib } \\
\text { ution } \\
0.47 \mathrm{~L} / \mathrm{kg}\end{array}$ & $\begin{array}{l}\text { Excretion } \\
\\
\text {. } \quad 3-38 \% \text { (urine); } \\
\text {. } \quad 3 \% \text { (feces). }\end{array}$ \\
\hline
\end{tabular}


Box 1. Cont.

\section{Dosage forms}

- Solution for inhalation;

- Intravenous injection;

- Oral solution;

- Effervescent tablets;

- Capsules;

- Tablets;

- Powder;

- Granule;

- Liquid;

- Ocular solution.
Overdosage

Single intravenous doses of NAC that were lethal:

- $1000 \mathrm{mg} / \mathrm{kg}$ in mice;

- $2445 \mathrm{mg} / \mathrm{kg}$ in rats;

- $1500 \mathrm{mg} / \mathrm{kg}$ in guinea pigs;

- $1200 \mathrm{mg} / \mathrm{kg}$ in rabbits;

- $500 \mathrm{mg} / \mathrm{kg}$ in dogs.

Symptoms of acute toxicity were ataxia, hypoactivity, labored respiration, cyanosis, loss of righting reflex, and convulsions.

Drug-drug interactions

- NAC can reduce the excretion of various drugs (e.g., pravastatin, valsartan, erythromycin, torasemide, lovastatin, liothyronine, digoxin, cerivastatin, raloxifene, caspofungin, enalapril, simvastatin, penicillamine);

- The serum concentration of eluxadoline can be increased when combined with NAC;

- The therapeutic efficacy of NAC can be decreased when used in combination with oxytetracycline, trypsin, or tetracycline.

Adapted from PubChem (2021) [31] and DrugBank (2021) [32].

\section{Mechanism of Molecular Action}

NAC is a thiol that acts as an acetylated precursor to the amino acid L-cysteine; it can reduce various radicals, by donating one electron, or acts as a nucleophile by donating one or two electrons (Figure 1) [33,34]. Its chemical structure, formed by the sulfhydryl functional group $(-\mathrm{SH})$ plus an acetyl group $\left(-\mathrm{COCH}_{3}\right)$ linked to the amino group $\left(\mathrm{NH}_{2}\right)$, is responsible for its metabolic activities related to the direct and indirect antioxidant action and mucolytic action [35].

\section{Mechanisms of molecular action}

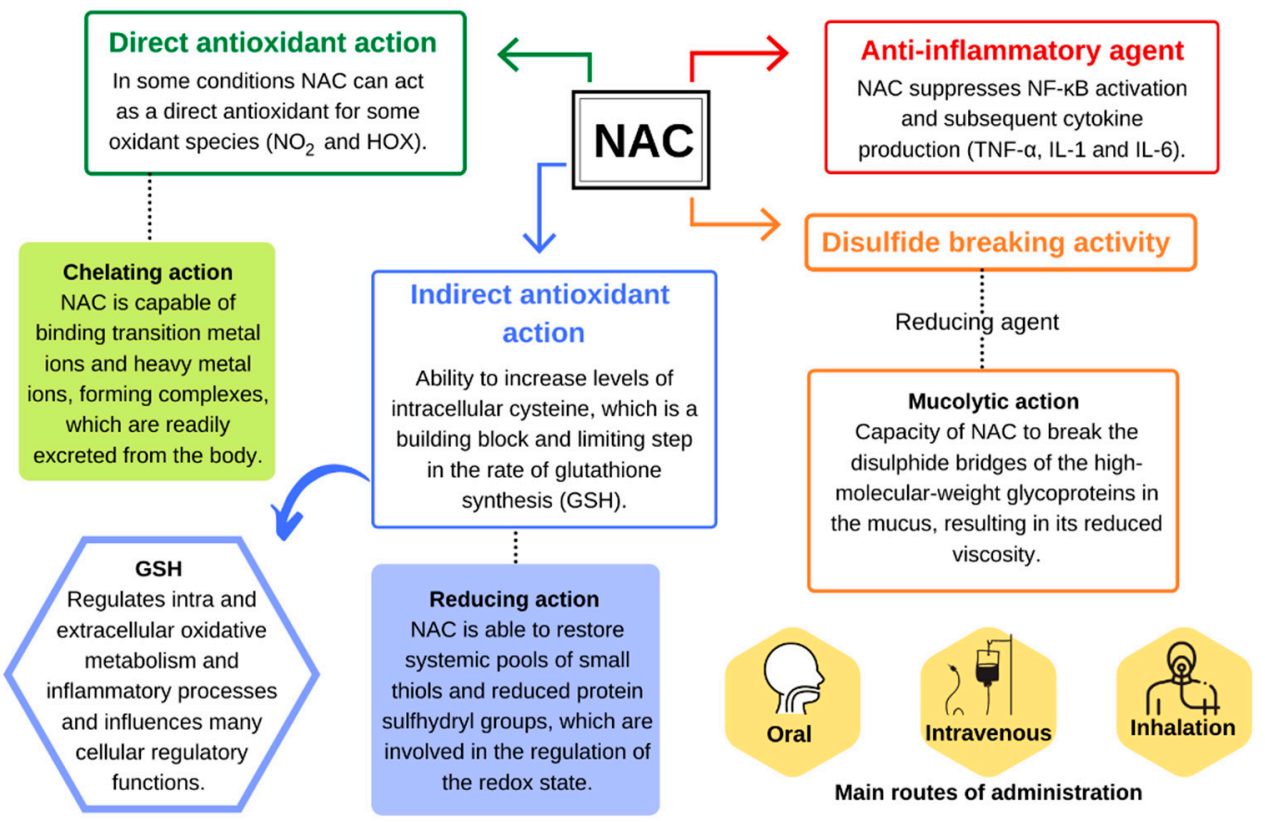

Figure 1. Mechanism of molecular action of N-acetylcysteine. Adapted from Aldini et al. (2018) [3].

The direct antioxidant activity of NAC is due to the ability of its free thiol group to react with reactive oxygen and nitrogen species (RONS) [36]. Under experimental conditions, NAC reacts quickly with the hydroxyl radical $\left({ }^{\bullet} \mathrm{OH}\right)$, nitrogen dioxide $\left({ }^{\bullet} \mathrm{NO}_{2}\right)$, carbon trioxide ion $\left(\mathrm{CO}_{3}{ }^{--}\right)$, and thiyl radical ( $\left.\mathrm{RS}^{\bullet}\right)$, in addition to the nitroxyl (HNO) that 
is the reduced and protonated form of nitric oxide $\left({ }^{\bullet} \mathrm{NO}\right)$ (Table 1$)$. Reactions with the radical anion superoxide $\left(\mathrm{O}_{2}{ }^{-}-\right)$, hydrogen peroxide $\left(\mathrm{H}_{2} \mathrm{O}_{2}\right)$, and peroxynitrite $\left(\mathrm{ONOO}^{-}\right)$ are relatively slow, as shown in Table 1 [34].

Table 1. Rate constants of $N$-acetylcysteine reactions with various compounds under different experimental conditions.

\begin{tabular}{|c|c|c|c|}
\hline Reactive Species & $\begin{array}{l}\text { Rate Constant } \\
\left(\mathbf{M}^{-1} \cdot \mathbf{s}^{-1}\right)\end{array}$ & $\begin{array}{l}\text { Experimental } \\
\text { Conditions }\end{array}$ & Ref. \\
\hline$\cdot \mathrm{OH}$ & $1.36 \times 10^{10}$ & $\mathrm{pH} 7, \mathrm{rt}$ & [37] \\
\hline$\cdot \mathrm{NO}_{2}$ & $\begin{array}{l}\approx 2.4 \times 10^{8 \mathrm{a}} \\
\approx 1.0 \times 10^{7 \mathrm{~b}}\end{array}$ & $\begin{array}{c}\mathrm{pH}>\mathrm{pKa}, \mathrm{rt} \\
\mathrm{pH} 7.4, \mathrm{rt}\end{array}$ & $\begin{array}{l}{[38]} \\
{[39]}\end{array}$ \\
\hline $\mathrm{CO}_{3}^{\bullet-}$ & $\begin{array}{c}\approx 1.0 \times 10^{7} \\
1.8 \times 10^{8}\end{array}$ & $\begin{array}{l}\mathrm{pH} 7, \mathrm{rt} \\
\mathrm{pH} 12, \mathrm{rt}\end{array}$ & [40] \\
\hline $\mathrm{HNO}$ & $5 \times 10^{5}$ & $\mathrm{pH} 7.4,37^{\circ} \mathrm{C}$ & [41] \\
\hline $\mathrm{O}_{2}^{\bullet-}$ & $\begin{array}{c}68 \pm 6 \\
\times 10^{3}\end{array}$ & 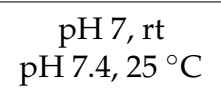 & $\begin{array}{l}{[37]} \\
{[42]}\end{array}$ \\
\hline $\mathrm{H}_{2} \mathrm{O}_{2}$ & $\begin{array}{l}0.16 \pm 0.01 \\
0.85 \pm 0.09\end{array}$ & $\begin{array}{l}\mathrm{pH} 7.4,37^{\circ} \mathrm{C} \\
\mathrm{pH} 7.4,25^{\circ} \mathrm{C}\end{array}$ & $\begin{array}{l}{[37]} \\
{[43]}\end{array}$ \\
\hline $\mathrm{ONOO}^{-}$ & $415 \pm 10$ & $\mathrm{pH} 7.4,37^{\circ} \mathrm{C}$ & [44] \\
\hline
\end{tabular}

Under physiological conditions, the reaction rate of NAC is usually lower when compared to other enzymatic and nonenzymatic antioxidants, as well as other substrates, which raises doubts about the relevance of its direct antioxidant capacity against RONS, especially when other factors are considered as its endogenous concentration and location (intra- or extracellular) [3,11]. However, depending on its relative concentration compared to other thiols, it is possible that NAC has some direct antioxidant effect against some oxidative species, including ${ }^{-} \mathrm{NO}_{2}$ and hypohalous acids (HOX) [3].

Like other thiols, experimental studies show that NAC through its free thiol can also bind to active redox metal ions, such as the ones from transition metals, copper $\left(\mathrm{Cu}^{2+}\right)$ and iron $\left(\mathrm{Fe}^{3+}\right)$, and heavy metals, cadmium $\left(\mathrm{Cd}^{2+}\right)$, mercury $\left(\mathrm{Hg}^{2+}\right)$, and lead $\left(\mathrm{Pb}^{2+}\right)$, forming complexes that are easily excreted by the body [34]. Although NAC is able to reduce levels of metal ions in cases of toxicity [45], clinical studies that evaluate its chelating properties are limited. It is still unclear whether NAC potentially acts as a chelator or whether the benefits found are predominantly related to its action as an indirect antioxidant via an increase in the intracellular tripeptide containing cysteine (L- $\gamma$-glutamyl-L-cysteinyl-glycine), better known as glutathione (GSH) [11].

GSH is the most abundant nonprotein thiol in the body and one of the main antioxidants responsible for maintaining cellular redox status, which, in addition to reacting directly with reactive species, acts as a cofactor or substrate for various antioxidant enzymes [3]. The intracellular concentration of cysteine is lower and, therefore, it acts as a limiting factor in the rate of GSH biosynthesis. This characteristic explains the role of NAC as a prodrug of cysteine and intracellular GSH [10].

The importance of NAC as a potent antioxidant is directly linked to its ability to increase levels of intracellular cysteine with subsequent increase in GSH (Figure 2). The isolated uses of both GSH and cysteine were not effective in raising GSH levels within cells, making NAC one of the major strategies to reduce the damage caused by oxidative stress in cases of xenobiotic intoxication, such as paracetamol or in pathologies related to GSH deficiency, through the maintenance of their levels in different tissues $[1,34,46]$. 
<smiles>CC(=O)N[C@@H](CS)C(=O)O</smiles>

\section{NAC}

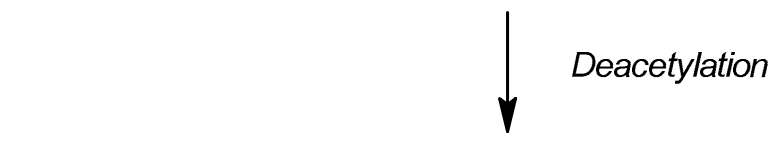<smiles>[R]C(C)=O</smiles>

\section{L-cysteine}<smiles>N[C@@H](CCC(=O)O)C(=O)O</smiles>

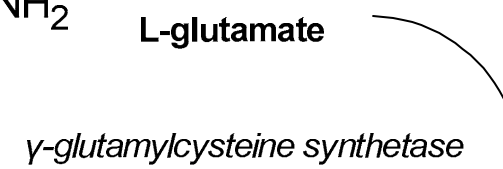
y-glutamylcysteine synthetase

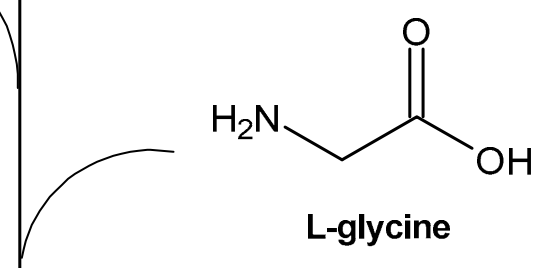<smiles>N[C@@H](CCC(=O)NC(CS)C(=O)NCC(=O)O)C(=O)O</smiles>

\section{Gluthatione (GSH)}

Figure 2. Chemical formula of $N$-acetylcysteine and its conversion to glutathione. Adapted from Rushworth and Megson (2014) [11].

In addition, NAC is also able to break down thiol proteins (such as cysteinylated extracellular proteins), releasing free thiols with higher antioxidant capacity, which potentiate GSH biosynthesis. Another mechanism linked to the indirect antioxidant activity exerted 
by NAC is related to its reducing capacity. NAC is capable of restoring systemic pools of low-molecular-weight (LMW) thiols and reduced protein sulfhydryl groups, which are involved in the regulation of the redox state, as is the case with mercaptoalbumin, which is the main antioxidant present in plasma and extracellular fluids [3].

Due to its reducing capacity, NAC also carries out one of its crucial activities as a potent expectorant. NAC is known as a mucolytic agent because it is able to reduce the disulfide bonds in crosslinked mucous proteins, interrupting their binding to the ligand and modifying their structures, thereby reducing the viscosity and elasticity of the mucus [34].

Experimental studies also describe the ability of NAC to alter the structure and/or function of proteins with (1) a reduction in the binding of the angiotensin II receptor in vascular smooth muscle cells [47]; (2) alteration of tumor necrosis factor (TNF- $\alpha$ ) receptor affinity for cytokines [48], and (3) a decrease in the capacity of transforming growth factor beta 1 (TGF- $\beta 1$ ) binding to the type III transforming growth factor receptor (T $\beta$ RIII) betaglycan [49].

Lastly, NAC also exerts anti-inflammatory activity by inhibiting the nuclear factor kappa-light-chain-enhancer of activated B cells (NF- $\mathrm{KB})$, which plays a critical role in the inflammatory cascade and immune response involved in the response to oxidative stress. NAC blocks the translocation and nuclear activation of the transcription factor NF- $\mathrm{kB}$, responsible for the regulation of proinflammatory gene expression $[9,36]$. NAC has been shown to suppress the release of inflammatory cytokines TNF $\alpha$, interleukin (IL)- $1 \beta$, and IL-6 in lipopolysaccharide-activated macrophages [50].

\section{Clinical Indications}

Figure 3 displays the therapeutic uses of NAC and Table 2 lists the performed clinical studies, highlighting doses, treatment time, and administration routes.

\section{Biological activities and therapeutic uses of NAC}

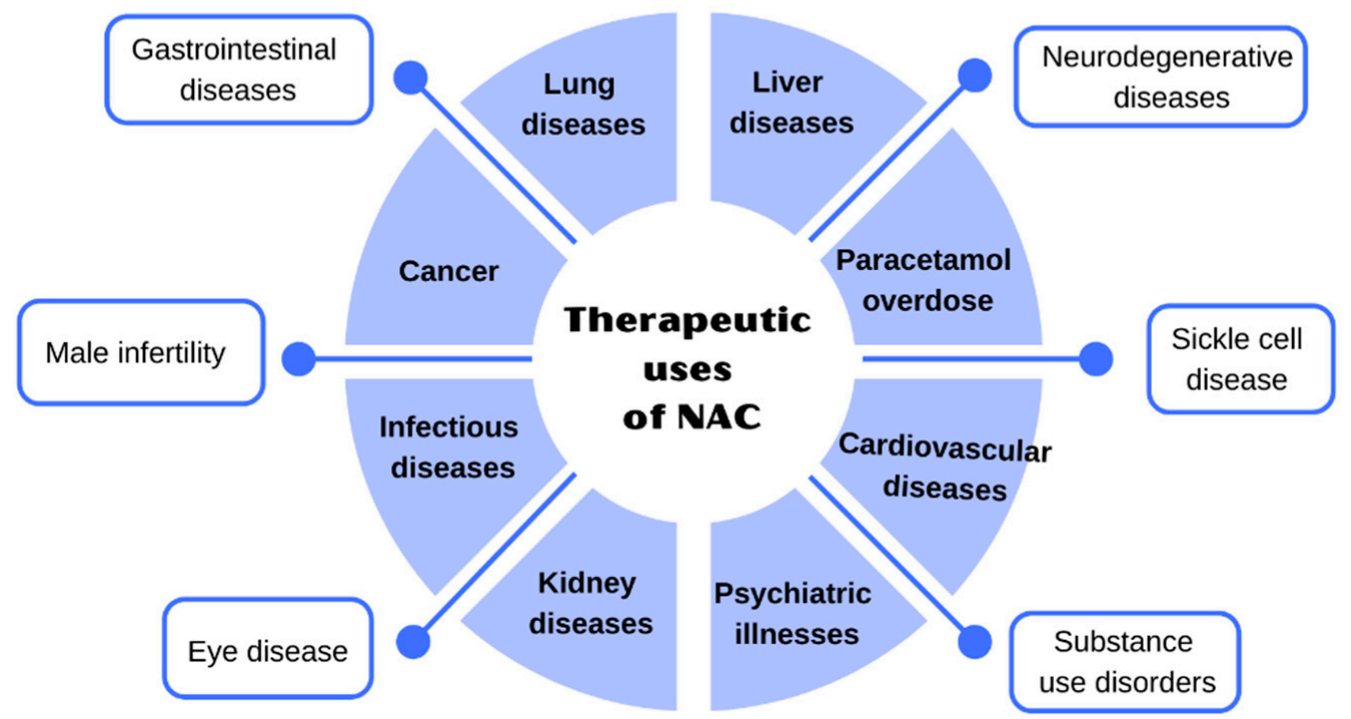

Biological activities

- Precursor of cysteine (replenishing cellular GSH levels);

- Elimination of reactive species;

- Binding transition and heavy metal ions;

- Disulphide breaking agent;

- Regulation of cell cycle and apoptosis;
- Signal transduction and gene expression;

- Affects cytoskeleton structure and trafficking;

- Immuno-modulatory activity;

- Affect mitochondrial processes;

- Anti-mutagenic and anti-neoplastic activities.

Figure 3. Biological activities and therapeutic uses of N-Acetylcysteine. Adapted from Samuni et al. (2013) [34]. 
Table 2. Studies carried out with $N$-acetylcysteine in different clinical conditions.

\begin{tabular}{|c|c|c|c|c|c|}
\hline Disease & Study Type & Dose & Treatment Type & $\begin{array}{l}\text { Administration } \\
\text { Routes }\end{array}$ & References \\
\hline \multicolumn{6}{|l|}{ Lung diseases } \\
\hline \multirow{8}{*}{ Chronic obstructive pulmonary disease } & Clinical trial & $600 \mathrm{mg} /$ day & 3 years & Oral & [51] \\
\hline & Clinical trial & $600 \mathrm{mg} /$ day & 3 years & Oral & [52] \\
\hline & Clinical trial NCT01136239 & $1200 \mathrm{mg} /$ day & 1 year & Oral & [53] \\
\hline & Clinical trial ChiCTR-TRC-09000460 & $1200 \mathrm{mg} /$ day & 1 year & Oral & [54] \\
\hline & Clinical trial NCT01599884 & $3600 \mathrm{mg} /$ day & 8 weeks & Oral & [55] \\
\hline & $\begin{array}{c}\text { Systematic } \\
\text { review with meta-analysis }\end{array}$ & $>600 \mathrm{mg} /$ day & Long term & Oral & [56] \\
\hline & $\begin{array}{c}\text { Systematic } \\
\text { review with meta-analysis }\end{array}$ & $\geq 1200$ mg/day & Long term & Oral & [57] \\
\hline & $\begin{array}{l}\text { Systematic } \\
\text { review }\end{array}$ & $\begin{array}{l}\text { Low doses: } \\
\leq 600 \mathrm{mg} / \text { day } \\
\text { High doses: } \\
>600 \mathrm{mg} / \text { day }\end{array}$ & Minimum of 6 months & Oral & [58] \\
\hline \multirow{3}{*}{ Cystic fibrosis } & $\begin{array}{c}\text { Systematic } \\
\text { review with meta-analysis }\end{array}$ & $600 \mathrm{mg}$ to $2800 \mathrm{mg} /$ day & 3.9 and 12 months & Oral or inhalation & [59] \\
\hline & Clinical trial & 1800,2400 and $3000 \mathrm{mg} /$ day & 4 weeks & Oral & [60] \\
\hline & $\begin{array}{l}\text { Clinical trial } \\
\text { 2007-001401-15 }\end{array}$ & $2400 \mathrm{mg} /$ day & 4 weeks & Oral & [61] \\
\hline \multirow{2}{*}{ Idiopathic pulmonary fibrosis } & $\begin{array}{c}\text { Systematic } \\
\text { review with meta-analysis }\end{array}$ & 704.8 to $1800 \mathrm{mg} /$ day & - & Oral or inhalation & [62] \\
\hline & $\begin{array}{c}\text { Systematic } \\
\text { review with meta-analysis }\end{array}$ & $\begin{array}{l}\text { Oral doses: } 1800 \mathrm{mg} / \text { day } \\
\text { Inhalation doses: } 704.8 \mathrm{mg}\end{array}$ & 3 to 15 months & Oral or inhalation & [28] \\
\hline \multirow{2}{*}{ Cardiovascular diseases } & Clinical trial & $15,000 \mathrm{mg} /$ day & $24 \mathrm{~h}$ & Intravenous & [63] \\
\hline & Clinical trial & $15,000 \mathrm{mg} /$ day & $24 \mathrm{~h}$ & Intravenous & [64] \\
\hline \multirow{3}{*}{ Cardiac surgery } & $\begin{array}{c}\text { Systematic } \\
\text { review with meta-analysis }\end{array}$ & $\begin{array}{c}<100 \mathrm{mg} / \mathrm{kg} / \\
\text { to } \geq 300 \mathrm{mg} / \mathrm{kg} / \text { day }\end{array}$ & $<24$ and $>48 \mathrm{~h}$ & Oral and/ or intravenous & [65] \\
\hline & $\begin{array}{c}\text { Systematic } \\
\text { review with meta-analysis }\end{array}$ & $50 \mathrm{mg} / \mathrm{kg}$ to $600 \mathrm{mg}$ & Until $48 \mathrm{~h}$ & Oral and/ or intravenous & [66] \\
\hline & Clinical trial & $50-150 \mathrm{mg} / \mathrm{kg}$ & $\begin{array}{c}1 \mathrm{~h} \text { preoperatively and } 48 \mathrm{~h} \\
\text { postoperatively }\end{array}$ & intravenous & [67] \\
\hline
\end{tabular}


Table 2. Cont.

\begin{tabular}{|c|c|c|c|c|c|}
\hline Disease & Study Type & Dose & Treatment Type & $\begin{array}{l}\text { Administration } \\
\text { Routes }\end{array}$ & References \\
\hline \multicolumn{6}{|l|}{ Psychiatric illnesses } \\
\hline \multirow{4}{*}{ Schizophrenia } & $\begin{array}{l}\text { Multicenter } \\
\text { clinical trial }\end{array}$ & $2000 \mathrm{mg} /$ day & 4 weeks & Oral & [68] \\
\hline & Clinical trial IRCT:2015080223463 & $1200 \mathrm{mg} /$ day & 12 weeks & Oral & [69] \\
\hline & Systematic review with meta-analysis & $600 \mathrm{mg}$ to $3600 \mathrm{mg} /$ day & $\geq 24$ weeks & Oral & [70] \\
\hline & $\begin{array}{c}\text { Clinical trial } \\
\text { NCT01354132 }\end{array}$ & $2700 \mathrm{mg} /$ day & 6 months & Oral & [71] \\
\hline \multirow{2}{*}{ Bipolar disorder } & Clinical trial ACTRN12612000830897 & $2000 \mathrm{mg} /$ day & 16 weeks & Oral & [72] \\
\hline & Clinical trial 12605000362695 & $1000 \mathrm{mg} /$ day & 24 weeks & Oral & [73] \\
\hline \multirow{2}{*}{ Depression } & $\begin{array}{c}\text { Clinical trial } \\
\text { ACTRN12607000134426 }\end{array}$ & $1000 \mathrm{mg} /$ day & 12 weeks & Oral & [74] \\
\hline & $\begin{array}{c}\text { Systematic } \\
\text { review with meta-analysis }\end{array}$ & $1000 \mathrm{mg}$ to $3000 \mathrm{mg} /$ day & - & Oral & [75] \\
\hline \multicolumn{6}{|l|}{ Neurodegenerative diseases } \\
\hline \multirow{3}{*}{ Parkinson's disease } & $\begin{array}{l}\text { Clinical trial } \\
\text { NCT01427517 }\end{array}$ & $150 \mathrm{mg} / \mathrm{kg}$ & $1 \mathrm{~h}$ & Intravenous & [76] \\
\hline & $\begin{array}{l}\text { Clinical trial } \\
\text { NCT02445651 }\end{array}$ & $\begin{array}{l}\text { Intravenous doses: } 50 \mathrm{mg} / \mathrm{kg} \\
\text { Oral doses: } 1000 \mathrm{mg} / \text { day }\end{array}$ & 3 months & Oral and intravenous & [77] \\
\hline & $\begin{array}{l}\text { Clinical trial } \\
\text { NCT02212678 }\end{array}$ & $6000 \mathrm{mg} /$ day & 4 weeks & Oral & [78] \\
\hline Alzheimer's disease & $\begin{array}{l}\text { Clinical trial } \\
\text { NCT00903695 }\end{array}$ & $600 \mathrm{mg} /$ day & 6 months & Oral & [79] \\
\hline \multirow{2}{*}{ Multiple sclerosis } & $\begin{array}{l}\text { Clinical trial } \\
\text { NCT02804594 }\end{array}$ & $1250 \mathrm{mg} /$ day & 4 weeks & Oral & [80] \\
\hline & $\begin{array}{l}\text { Clinical trial } \\
\text { NCT03032601 }\end{array}$ & $\begin{array}{l}\text { Intravenous doses: } 50 \mathrm{mg} / \mathrm{kg} \text { (once a week) } \\
\text { Oral doses: } 1000 \mathrm{mg} / \text { day (6 times a week) }\end{array}$ & 2 months & Oral and Intravenous & [81] \\
\hline \multicolumn{6}{|l|}{ Liver diseases } \\
\hline Paracetamol poisoning & Guide clinical practice & $200 \mathrm{mg} / \mathrm{kg}$ in $4 \mathrm{~h}$, then $100 \mathrm{mg} / \mathrm{kg}$ in $16 \mathrm{~h}$ & $20 \mathrm{~h}$ & Intravenous & [82] \\
\hline
\end{tabular}


Table 2. Cont.

\begin{tabular}{|c|c|c|c|c|c|}
\hline Disease & Study Type & Dose & Treatment Type & $\begin{array}{l}\text { Administration } \\
\text { Routes }\end{array}$ & References \\
\hline \multirow{2}{*}{ Acute liver failure } & Randomized case control study & $\begin{array}{c}150 \mathrm{mg} / \mathrm{kg} \text { over } 1 \mathrm{~h} \text {, followed by } \\
12.5 \mathrm{mg} / \mathrm{kg} / \mathrm{h} \text { for } 4 \mathrm{~h} \text { and continuous infusion } \\
\text { of } 6.25 \mathrm{mg} / \mathrm{kg} / \mathrm{h} \text { for the remaining } 67 \mathrm{~h}\end{array}$ & $72 \mathrm{~h}$ & Intravenous & [83] \\
\hline & $\begin{array}{l}\text { Systematic } \\
\text { review }\end{array}$ & $\begin{array}{c}150 \mathrm{mg} / \mathrm{kg} \text { over } 1 \mathrm{~h} \text {, followed by } \\
12.5 \mathrm{mg} / \mathrm{kg} / \mathrm{h} \text { for } 4 \mathrm{~h} \text {, and continuous infusions } \\
\text { of } 6.25 \mathrm{mg} / \mathrm{kg} / \mathrm{h} \text { for the remaining } 67 \mathrm{~h}\end{array}$ & $72 \mathrm{~h}$ & Intravenous & [84] \\
\hline Nonalcoholic fatty liver disease & Clinical trial & $600 \mathrm{mg} /$ day & 3 months & Oral & [85] \\
\hline Acute alcoholic hepatitis & Multicenter clinical trial & $300 \mathrm{mg} / \mathrm{kg}$ & 14 days & Intravenous & [87] \\
\hline \multicolumn{6}{|c|}{ Kidney diseases } \\
\hline $\begin{array}{l}\text { Chronic renal patients } \\
\text { undergoing cardiac }\end{array}$ & $\begin{array}{c}\text { Systematic } \\
\text { review with meta-analysis }\end{array}$ & $150 \mathrm{mg} / \mathrm{kg}$ to $1200 \mathrm{mg}$ & $6 \mathrm{~h}$ to 7 days & Intravenous & [88] \\
\hline \multirow[b]{2}{*}{ Chronic kidney disease } & Clinical trial & $5000 \mathrm{mg}$ & One hemodialysis session & Intravenous & [89] \\
\hline & Clinical trial & $600 \mathrm{mg} /$ day & $\begin{array}{l}2 \text { doses with } \\
1 \text { week interval }\end{array}$ & Oral & {$[90]$} \\
\hline \multicolumn{6}{|l|}{ Gastrointestinal diseases } \\
\hline \multirow{2}{*}{ Helicobacter pylori infection } & Clinical trial & $600 \mathrm{mg} /$ day & 14 days & Oral & [91] \\
\hline & Clinical trial & $800 \mathrm{mg} /$ day & 5 days & Oral & [92] \\
\hline Colon cancer associated with colitis & $\begin{array}{l}\text { Systematic } \\
\text { review }\end{array}$ & $8000 \mathrm{mg}$ to $1200 \mathrm{mg} /$ day & 7 days to 12 weeks & Oral & [93] \\
\hline \multirow[t]{2}{*}{ Gastrointestinal cancer } & Clinical trial & $1200 \mathrm{mg} /$ day & $\begin{array}{l}2 \text { days before surgery until } \\
\text { the fifth day } \\
\text { postoperatively }\end{array}$ & Schematic parenteral & [94] \\
\hline & Clinical trial & $800 \mathrm{mg} /$ day & 12 weeks & Oral & [95] \\
\hline Ulcerative colitis & Clinical trial & $800 \mathrm{mg} /$ day & 4 weeks & Oral & [96] \\
\hline \multicolumn{6}{|l|}{ Infectious diseases } \\
\hline Chronic hepatitis B & Clinical trial & $8000 \mathrm{mg} /$ day & 28 days & Intravenous & [97] \\
\hline Pulmonary tuberculosis & Clinical trial & $600 \mathrm{mg} /$ day & 2 months & Oral & [98] \\
\hline SARS-CoV-2 & $\begin{array}{l}\text { Clinical trial } \\
\text { NCT04374461 }\end{array}$ & $6000 \mathrm{mg} /$ day & 3 weeks & Intravenous & [99] \\
\hline
\end{tabular}


Table 2. Cont.

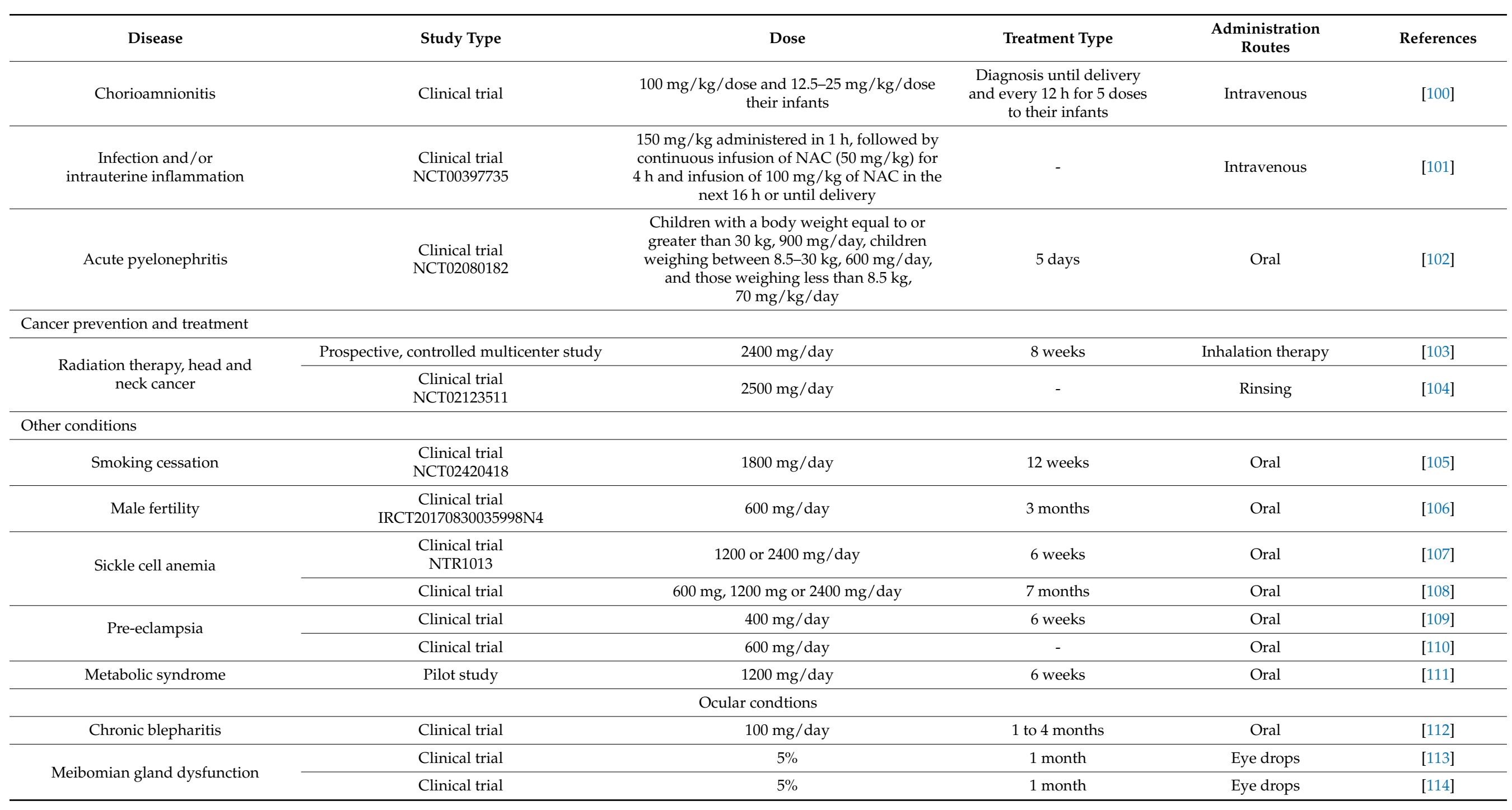




\subsection{Lung Diseases}

The pathogenesis and progression of respiratory diseases can be explained by inflammation and increased oxidative stress, with a consequent reduction in endogenous antioxidants, such as GSH $[115,116]$. NAC represents a promising therapeutic target for the treatment of these diseases, including chronic obstructive pulmonary disease (COPD), cystic fibrosis (CF), and idiopathic pulmonary fibrosis (IPF), due to its antioxidant, antiinflammatory, and mucolytic properties already described, related to its ability to replenish the GSH intracellular pool and reduce mucus production and viscosity $[55,116]$ (Figure 3).

Typically, NAC is administered orally, using $600-1200 \mathrm{mg}$ tablets up to three times a day [11]. For the treatment of chronic diseases such as COPD, which requires long-term use, the maximum licensed dose is $600 \mathrm{mg} /$ day, but doses above $600 \mathrm{mg}$ /day are constantly used in different clinical trials. The safety profile of NAC is usually similar, both for low doses ( $\leq 600 \mathrm{mg} /$ day) and for high doses ( $>600 \mathrm{mg} /$ day). Studies with a dosage up to $3000 \mathrm{mg} /$ day in respiratory diseases have shown that NAC is safe and well tolerated [27] (Table 2).

The clinical efficacy of NAC for the treatment of patients with COPD has been documented in several clinical trials (Table 2); however, the results are still controversial. COPD is characterized by chronic symptoms related to airflow obstruction determined by the inhalation of toxic agents, being frequent in smoking patients. The BRONCUS (bronchitis randomized on NAC cost-utility study) study, a phase III, double-blind, randomized, placebo-controlled trial, followed 523 COPD patients for 3 years. Patients were treated with $600 \mathrm{mg}$ per day of oral NAC versus placebo. The study demonstrated that treatment with low dosage of NAC did not affect the rate of decline in forced expiratory volume in $1 \mathrm{~s}$ (FEV 1) or vital capacity, nor did it affect the rate of exacerbation or the health status of patients with COPD [51]. Another clinical trial with the same oral dosage of $600 \mathrm{mg}$ of NAC per day also showed no impact on the evolution of respiratory quality of life or on the rate of exacerbations in patients with chronic bronchitis or mild to moderately severe COPD [52].

Unlike the results found in previous studies, the effect of high dose $\mathrm{N}$-acetylcysteine on air trapping and airway resistance of chronic obstructive pulmonary disease, a doubleblinded, randomized, placebo-controlled trial (HIACE) conducted with 120 patients with stable COPD (58 treated with $600 \mathrm{mg}$ of oral NAC twice a day and 62 with placebo), demonstrated a significant improvement in the function of the small airways, in addition to a reduction in the frequency of exacerbation of the disease [53]. Similarly, the placebocontrolled study on efficacy and safety of $\mathrm{N}$-acetylcysteine high dose in exacerbations of chronic obstructive pulmonary disease held (PANTHEON) with 1006 patients with moderate and severe COPD, treated with $1200 \mathrm{mg}$ of oral NAC per day, resulted in a significant reduction in acute exacerbations of COPD in the treated group compared to the placebo group, especially in patients with moderate disease [54].

The same finding was not found in the randomized, double-blind, placebo-controlled trial that compared the use of high-dose NAC (1800 mg twice a day, totaling $3600 \mathrm{mg} /$ day) versus placebo for 8 weeks in COPD patients. The trial, while showing that high doses are well tolerated when used for a short time, did not produce positive effects on general respiratory health, lung function, or circulating measures of systemic oxidative stress and inflammation [55].

According to Tse et al. (2013) [53], treatment with low doses of NAC and the use of FEV 1 as a parameter for the evaluation of COPD in some studies may be responsible for the lack of effectiveness of the antioxidant and anti-inflammatory treatment of NAC in these patients. In general, higher doses generate greater bioavailability of NAC, increasing its effects. Thus, the authors suggested that low concentrations of NAC $(600 \mathrm{mg} /$ day $)$ are unlikely to produce significant antioxidant and anti-inflammatory effects in improving lung function, exacerbation rate or risk of hospital readmission. However, higher doses can reduce the effects caused by oxidative stress and inflammation in COPD, demonstrating a positive impact on the rate of exacerbation [117]. 
In this perspective, in order to better elucidate the results of clinical trials, different meta-analyses examined the effects of NAC on COPD, using, as criteria for evaluation, the total number of exacerbations, number of patients with at least one exacerbation, and decline in FEV $1[56,57]$. Shen et al. (2013) [56] showed that long-term treatment with high doses of NAC (>600 mg/day) can reduce exacerbations in COPD, with no effect on the FEV 1 rate. Another meta-analysis also showed that prolonged treatment with higher doses of NAC $(\geq 1200 \mathrm{mg} /$ day) prevents exacerbations of COPD, while lower doses ( $600 \mathrm{mg}$ /day) may be effective only for patients with chronic bronchitis, without COPD and without airway obstruction [57].

A more recent systematic review [58] that included a sample of 2691 participants, randomly assigned to the NAC $(n=1339)$ and control $(n=1352)$ groups, showed that treatment with low-dose NAC ( $\leq 600 \mathrm{mg} /$ day) or high-dose NAC ( $>600 \mathrm{mg} /$ day), for a minimum period of 6 months, can safely reduce the risk of COPD exacerbation, without adverse effects. However, NAC therapy had no effect on the rate of exacerbation or the parameters of pulmonary function (FEV 1). Cazzola et al. (2017) [118] also demonstrated that the use of high doses of NAC (1200 mg/day) as adjunctive therapy in patients with COPD can reduce the chances of exacerbations of the disease. On the basis of the results available up to date, the Global Initiative for Chronic Obstructive Lung Disease [119] recognizes that mucolytic and antioxidant drugs, such as NAC, can be used as an adjunct therapy to reduce the risk of acute exacerbation of COPD, but in a limited way due to the lack of robust randomized controlled clinical trials (level of evidence B).

In relation to the treatment of $\mathrm{CF}, \mathrm{NAC}$ is often used in view of its mucolytic properties, through the hydrolysis of the disulfide bonds responsible for the connection of the mucin molecules [120]. Consequently, since the 1960s, the drug has been approved as an inhalation therapy for patients diagnosed with $\mathrm{CF}$, but its effects on improving lung function or reducing pulmonary exacerbations have not yet been fully established [121,122].

Thus, the findings regarding the inhalation of NAC in patients diagnosed with CF are especially focused on its effectiveness in eliminating mucus secretion. In a systematic review with meta-analysis that aimed to synthesize the existing knowledge between antioxidants and the pulmonary function of individuals with $\mathrm{CF}$, the authors recommended the administration of NAC (primarily by inhalation) as an adjunct to treatment, as it became evident that oral supplementation of NAC exhibited beneficial effects in preventing deterioration of lung function, but not significantly. Conversely, when used by inhalation, NAC resulted in a significantly favorable effect on lung function in adults after 3 months, being kept after 9 and 12 months [59].

CF patients characteristically exhibit recurrent infections/inflammations of the respiratory tract, which is consistent with an increase in oxidative stress. Therefore, $18 \mathrm{CF}$ patients were scheduled for treatment with high doses of NAC $(600,800$, and $1000 \mathrm{mg} /$ day) three times a day, for a period of 4 weeks. In the end, the authors concluded that the high doses were able to raise the levels of GSH in blood neutrophils and the neutrophil count in the airways, with a significant reduction in elastase activity, the results being justified by the role of NAC in inhibiting the NF-KB pathway, causing a reduction in IL-8. Doses used were well tolerated by patients, while only mild adverse effects were reported (heartburn, nausea, flatulence) [60].

Subsequently, the use of NAC was reported in a randomized clinical study, in which the effect of 4 weeks of oral supplementation of NAC ( $2400 \mathrm{mg} /$ day) on the oxidative stress markers in adults with CF and chronic pulmonary infection was evaluated, where it was concluded that there was an improvement in pulmonary function, but without reductions in lipid peroxidation, malondialdehyde (MDA), and 8-isoprostane markers. Nevertheless, the treatment was seen as well tolerated, despite one of the 11 participants dropping out of the study due to stomach pain [61].

On the basis of its antioxidant and anti-inflammatory activities, NAC has been used in different clinical trials as an option to treat patients with IPF in combination with standard therapies [28]. IPF is a chronic, progressive interstitial lung disease, of unknown etiology, 
which has a high mortality rate [123]. It is characterized by worsening dyspnea and lung function, as a result of abnormal wound healing in the interstitial and alveolar spaces of the lung, associated with the intense proliferation of myofibroblasts, which results in fibrosis. Inflammation and oxidative stress are part of its pathogenesis and are associated with disease progression [124,125].

It is speculated that NAC may be an effective therapeutic resource by inhibiting oxidation and restoring redox balance in patients with IPF [28]. Nevertheless, in 1989, the study by Cantin et al. [126] showed that patients with IPF had a fourfold lower concentration of GSH when compared to healthy individuals, suggesting that GSH deficiency in these patients contributes to the oxidative-antioxidant imbalance of the lower respiratory tract, causing greater damage to the cells of the lung parenchyma. In the same study, the authors suggested that restoring GSH levels in patients with IPF could be a rational therapeutic approach.

A clinical trial evaluated the effectiveness of inhaled NAC monotherapy in Japanese patients with mild to moderate IPF for a period of 48 weeks. Patients were randomly assigned to the NAC $(n=51)$ and control $(n=49)$ groups. The treated group received inhalation twice a day, with $352.4 \mathrm{mg}$ of NAC diluted with saline, to a total volume of $4 \mathrm{~mL}$, through MicroAir nebulizers and vibrating mesh technology. The control group did not receive any treatment or placebo during the research. Of the 100 participants, 76 completed the study (38 in each group). There were no significant general differences in the change in forced vital capacity (FVC) between the groups. Changes in other parameters, such as changes in lower arterial oxygen saturation, 6 min walking distance test (6MWD), and abnormal pulmonary function parameters (PFT) also did not show significant differences between the NAC and control groups. Regarding the safety of inhaled NAC, there were no significant differences in the number of adverse events reported for both groups, demonstrating that, in general, NAC was well tolerated. Bacterial pneumonia, cough, sore throat, and hypercholesterolemia were the most common adverse effects reported by participants [25].

Rogliani et al. (2016) [62], in their systematic review and meta-analysis, analyzed the efficacy and safety of drugs frequently used in IPF, pirfenidone and nintedanib, in addition to NAC, in 3847 patients (2254 treated and 1593 placebo). The study showed that both pirfenidone and nintedanib, but not NAC, were significantly effective in reducing the progression of IPF. In addition, the study also d attention to the safety of NAC (concentrations of $704.8 \mathrm{mg}$ /day inhaled at $1800 \mathrm{mg}$ /day in tablet form), suggesting a higher risk of adverse events, despite insignificant results.

Another recent meta-analysis [28], which included 21 studies published between 2005 and 2016, assessed the efficacy and safety of NAC therapy in IPF. Of the 1354 patients, 695 received NAC alone orally or inhaled or combined with other medications (commonly corticosteroids and pirfenidone) and 659 received other therapies. The commonly used oral dose was $1800 \mathrm{mg}$ per day and the inhalation dose was $704.8 \mathrm{mg}$. Analysis of the data showed that NAC can decrease the decline in lung function in patients with IPF, related to the reduction in the decline in forced vital capacity (FVC) and in the diffusion capacity of carbon monoxide (DLCO), with slow disease progression due to stabilizing arterial oxygen partial pressure $\left(\mathrm{PaO}_{2}\right)$. Additionally, the administration of NAC also improved the results of the 6 min walking distance test, corroborating the results of Sun et al. (2016) [123].

\subsection{Cardiovascular Diseases}

As with other diseases, oxidative stress is involved in the development and progression of cardiovascular disease (CVD). Clinical and especially experimental studies have shown the effectiveness of NAC in improving cardiac function, highlighting its cardioprotective role in conditions such as diabetic cardiomyopathy (DCM), acute myocardial infarction (AMI), heart failure (HF), and coronary artery disease (CAD) [127].

The multicenter clinical trial NACIAM ( $N$-acetylcysteine in acute myocardial infarction), conducted with patients with ST-segment elevated myocardial infarction (STEMI) 
undergoing primary percutaneous coronary intervention, demonstrated that the combined treatment of high doses of intravenous NAC $(20 \mathrm{mg} / \mathrm{min}$ in the first hour and $10 \mathrm{mg} / \mathrm{min}$ in the remaining $47 \mathrm{~h}$ ) combined with a low dose of nitroglycerin $(2.5 \mathrm{Pg} / \mathrm{min}$ for $48 \mathrm{~h})$ was effective in reducing the size of acute infarction in these patients. The study also demonstrated that NAC improves myocardial rescue and acts in the faster resolution of chest pain in these patients, presenting itself as an adjunctive therapeutic proposal with a potential beneficial effect on primary percutaneous coronary intervention [128].

Other studies have also demonstrated positive effects on this therapeutic association $[63,129]$, suggesting that NAC, in addition to acting as a potent antioxidant, potentiates the effects of nitroglycerin. In the study by Arstall et al. (1995) [63], the combined treatment of $15,000 \mathrm{mg}$ of intravenous NAC over $24 \mathrm{~h}$ with nitroglycerin and streptokinase reduced oxidative stress in patients with AMI, measured by the higher proportion of reduced and oxidized glutathione (GSH/GSSG) in patients treated with NAC, associated with lower plasma malondialdehyde (MDA) levels and better preservation of left-ventricular function. In the study, all patients received an infusion of $5 \mu \mathrm{g} / \mathrm{min}$ of nitroglycerin before the start of the clinical trial. The treated group received an intravenous infusion of NAC, at $20 \mathrm{mg} / \mathrm{min}$ in the first hour, followed by $10 \mathrm{mg} / \mathrm{min}$ in the subsequent $23 \mathrm{~h}$, totaling a dose of 15,000 $\mathrm{mg}$ in $24 \mathrm{~h}$. After the initiation of NAC infusion, $100 \mathrm{mg}$ of hydrocortisone was also administered, followed by $1.5 \mathrm{MU}$ of intravenous streptokinase for $30 \mathrm{~min}$. The control group did not receive the NAC infusion. Similarly, another study showed that the combined administration of intravenous NAC (15,000 mg/24 h), with nitroglycerin and streptokinase, significantly reduced plasma MDA levels and improved left-ventricular function in patients with AMI [64].

The use of NAC has also been explored in patients undergoing cardiac surgery. Studies have suggested that NAC is able to reduce postoperative complications in these patients, by reducing oxidative stress and inflammation [130,131]. However, a recent systematic review with 29 clinical trials and 2486 participants showed that NAC in different routes of administration (intravenous, oral, oral plus intravenous) and doses $(<100,100$ to $<300$, $\geq 300 \mathrm{mg} / \mathrm{kg} /$ day) did not demonstrate significant efficacy in reducing the main adverse outcomes associated with cardiac surgery, such as mortality, acute renal failure, heart failure, length of stay and/or intensive care unit, arrhythmia, and acute myocardial infarction [65].

Another meta-analysis [66] also found no evidence that intravenous and/or oral administration of NAC in different therapeutic regimens (ranging from $50 \mathrm{mg} / \mathrm{kg}$ to $600 \mathrm{mg}$ doses) in 578 patients had an effect on mortality. However, treatment with NAC reduced postoperative atrial fibrillation, which is a common type of arrhythmia after cardiac surgery and which can have an impact on the length of hospital stay of patients. Ozaydin et al. (2008) [67] also demonstrated that the rate of atrial fibrillation in the group treated with NAC, administered intravenously in doses of 50-150 mg/kg, $1 \mathrm{~h}$ preoperatively and $48 \mathrm{~h}$ postoperatively, was lower when compared to the placebo group. It is speculated that atrial fibrillation is related to increased oxidative stress and chronic inflammation due to GSH depletion [132]. Thus, current data reveal that NAC in patients after cardiothoracic surgery is effective in preventing arrhythmias, requiring further randomized clinical trials to assess other outcomes related to postoperative complications [133].

\subsection{Psychiatric Illnesses}

NAC has been recognized as a potential therapeutic strategy for psychiatric illnesses, including compulsive disorders, schizophrenia, bipolar disorder (BD), and depression. Its impact on the reduction of inflammatory cytokines, associated or not with oxidative processes, helps to explain the mechanism via which NAC can modulate the symptoms of psychiatric disorders [134]. A review based on current pieces of evidence [135] suggests that the etiology and progression of psychiatric disorders involve the deterioration of cerebral energy metabolism, mitochondrial functions, and redox imbalance, associated with environmental and genetic factors that have a clinical role not only in the characteristic 
symptoms of the disease, but also in the alteration of the circadian and metabolic rhythms of the individuals.

Schizophrenia is a psychiatric disorder characterized by positive symptoms, such as delusions and hallucinations, and negative symptoms, such as withdrawal from the environment, avolition, and blunted affection [135]. Clinical trials conducted with schizophrenic patients have shown that NAC is a safe and effective adjuvant therapy to improve the clinical outcomes of chronic schizophrenia $[68,69,136]$.

A multicenter trial [68] evaluated the safety and efficacy of oral supplementation of $2000 \mathrm{mg}$ of NAC per day associated with treatment with antipsychotic medication and demonstrated moderate benefits for treatment with NAC, which reduced the clinical severity measured by the Clinical Global Impression (CGI) scale and the Positive and Negative Syndrome Scale (PANSS). Additionally, Sepehrmanesh et al. (2018) [69] showed that the administration of $1200 \mathrm{mg}$ of NAC had a positive impact on the positive, negative, general, and total psychopathological symptoms analyzed by PANSS, along with an improvement of cognitive performance. A meta-analysis also supported that NAC administered for a period of 24 weeks or more improves the symptoms of schizophrenia, as well as the cognitive domain of working memory, where studies had a daily dose range of $600 \mathrm{mg}$ to $3600 \mathrm{mg}$ [70].

Other clinical studies have analyzed the effect of NAC supplementation, based on glutamatergic neurotransmission via glycine reuptake at the $N$-methyl-D-aspartate (NMDA) receptor as a possible therapeutic target for the improvement of schizophrenia symptoms [137-140]. It is known that glutamate is an excitatory neurotransmitter in the brain, whose dysfunction in physiological control can contribute to the development of schizophrenia and other neuropsychiatric disorders. Evidence shows that the symptoms, cognitive deficits, and neurophysiological indices of schizophrenia can be reproduced by blocking these receptors [141]. NMDA is a receptor sensitive to redox reactions, inhibited by increased oxidative stress. Thus, the role of NAC as a precursor to GSH is to regulate the redox system and favor the function of the NMDA receptor [142].

In fact, the increases in oxidative stress in blood, cerebrospinal fluid in postmortem samples, and particular deficits in the glutathione system (unregulated GSH redox, GSH peroxidase and GSH reductase enzymes) are closely linked to the pathophysiology of schizophrenia and, by association, with etiopathology, as well as with worsening of symptoms to functional consequences [143]. A randomized clinical trial aiming to evaluate the impact of supplementation of $2700 \mathrm{mg} /$ day of NAC for 6 months in patients with schizophrenia in standard treatment (antipsychotics, mood stabilizers, and/or benzodiazepine) identified that the supplementation was not able to improve the symptomatic and functional results, but increased the levels of glutathione in the brain and neurocognition (i.e., processing speed), while there was also a blood increase in GSH peroxidase activity [71].

Among mood disorders, BD and major depressive disorders (MDD) are the most prevalent. For $\mathrm{BD}$, the literature suggests that mitochondrial dysfunction is involved in its pathogenesis. Thus, interventions that have an effect on mitochondrial function can act in the clinical improvement of depressive symptoms in BD. However, a randomized, placebo-controlled clinical trial conducted with 181 participants failed to demonstrate these effects from supplementing $2000 \mathrm{mg} /$ day of NAC alone or combined with other antioxidants in patients with $\mathrm{BD}$ and depressive symptoms [72].

In MDD, inflammatory and oxidative processes seem to be part of the pathophysiology of depression. Inflammation markers, proinflammatory cytokines, acute phase proteins, and adhesion molecules are usually elevated in patients with this disorder, contributing to neuroinflammation that appears to be associated with structural and functional abnormalities in the brain and a lower therapeutic response [144]. Although NAC is a strong candidate for adjunctive treatment of depression, oral supplementation of $1000 \mathrm{mg} /$ day ( 2 capsules of $500 \mathrm{mg}$ twice daily) associated with the usual treatment of the disease, when compared to placebo, did not produce positive effects on treatment of individuals with 
MDD (moderate to severe) at the end of 12 weeks. However, secondary analysis revealed a more promising effect among patients with more severe depression [74]. Magalhães et al. (2011) [73] managed to demonstrate interesting results with the oral administration of $1000 \mathrm{mg} /$ day in a small sample of patients (14 individuals) with BD II related to complete remission of depressive and manic symptoms in the treated group.

Additionally, Kishi et al. (2020) [75], when conducting a systematic review with metaanalysis from clinical, randomized, and double-blind studies evaluating NAC as an adjunct treatment in cases of bipolar depression and MDD, concluded that, despite NAC being able to reduce the score on the Global Clinical Impression Severity Scale, no significant improvement in symptoms was found.

Lastly, it is noted that the recommendations for the use of NAC as an adjunct therapeutic strategy in most psychiatric disorders are still limited. A clinical trial that aims to investigate the clinical efficacy of NAC supplementation in patients with MDD associated with its potential effects on inflammation and oxidative stress is ongoing (ID ClinicalTrials.gov NCT02972398).

\subsection{Neurodegenerative Diseases}

NAC has neurogenic and neuroprotective properties, since, unlike the administration of GSH and L-cysteine, NAC has the ability to effectively cross the blood-brain barrier, raising GSH levels in the brain, exhibiting anti-inflammatory actions, and acting on essential neurotransmitter systems, in addition to acting on glutamate [145]. Another aspect of this drug is the modulation of NMDA, which, when modified (hyperactivity or hypofunction), is responsible for neurological and psychiatric changes [146].

Taking into account oxidative damage, glutathione depletion, and/or NMDA receptor dysregulation in Parkinson's disease, Alzheimer's disease, and multiple sclerosis, high levels of RONS markers (lipid hydroperoxides, MDA, and superoxide dismutase activity-SOD) were found in Parkinson's disease patients, along with reduced catalase activity. Furthermore, it has been suggested that MDA may be used as a biomarker in this disease, while SOD and lipid hydroperoxides may be associated with late disease characteristics [147].

In this sense, alternative therapies that elevate GSH and act on oxidative stress are often tested as modifiers of these diseases, such as NAC supplementation [148]. Thus, a study administering a single intravenous dose of NAC $(150 \mathrm{mg} / \mathrm{kg})$ in subjects with Parkinson's disease revealed an increase in the blood GSH/GSSG and cerebral GSH ratio [76]. Similarly, 42 patients with Parkinson's disease were tested with weekly intravenous doses of NAC $(50 \mathrm{mg} / \mathrm{kg}$ ) and higher oral doses (500 $\mathrm{mg}$ twice a day) for 3 months, in which the binding of the dopamine transporter was measured via brain images. The results suggested that supplementation could positively affect the patients' dopaminergic system, which in turn had improved clinical effects [77]. However, intravenous administration is not sustainable in the long term; thus, a controlled clinical trial administered oral doses of $6000 \mathrm{mg} /$ day in individuals with Parkinson's, where they observed blood increases in antioxidant capacity (GSH/GSSG and catalase), but not in GSH cerebral level, possibly reflecting the low oral bioavailability when compared to the intravenous application [78].

In Alzheimer's disease, NAC supplementation has been used as a plausible alternative for a future drug associated with a nutraceutical formulation, since, in several studies, the effect of NAC was evaluated in conjunction with other substances [149]. In a placebocontrolled clinical trial, individuals with mild cognitive impairment consumed $600 \mathrm{mg}$ of NAC (associated with folate, alpha-tocopherol, vitamin B12, S-adenosylmethionine, and acetyl-L-carnitine) daily for 6 months and obtained improvement in the assessment scale of dementia and preservation of cognitive function [79].

NAC supplementation benefits those who suffer from multiple sclerosis (MS), a neurological disorder associated with white- and gray-matter lesions, with inflammation and oxidative damage mediated immunologically, specifically via reduced brain levels of GSH [150-152]. From this perspective, studies have suggested that antioxidant in- 
terventions can attenuate the frequent neurodegenerative processes in the disease [153]. Thus, a study with NAC and patients with MS identified improvements in cerebral glucose metabolism, cognition, and attention after administration of intravenous doses up to $50 \mathrm{mg} / \mathrm{kg}$ (once a week) and oral doses up to $1000 \mathrm{mg} /$ day (6 times a week) [81]. In another study, randomized patients were supplemented with $1250 \mathrm{mg}$ of NAC, in which no significant results were found in fatigue reduction outcomes, as well as changes in GSH levels in individuals with multiple sclerosis [80].

Therefore, more studies are needed to understand the effects of NAC in neurodegenerative diseases, as a function of the metabolic level, dosages, frequencies, route of administration, and clinical markers.

\subsection{Liver Diseases}

Acute and chronic liver diseases are highly prevalent worldwide, representing an important cause of morbidity and mortality [154]. Oxidative stress is a crucial factor in the pathogenesis of these diseases, participating in the liver's fibrogenic response and stimulating its progression [155]. The efficacy of NAC in modulating inflammation and oxidative stress in liver diseases has already been analyzed through a wide systematic review of experimental and clinical studies that evaluated the antioxidant and anti-inflammatory roles of NAC in reducing liver damage [9].

NAC is widely accepted as a safe and effective drug to treat paracetamol poisoning. Its pathogenesis is already well understood and involves toxic effects on the liver due to the excessive production of $N$-acetyl- $p$-benzo-quinone imine (NAPQI), which is a hepatotoxic metabolite that under normal conditions is easily inactivated by liver GSH. However, in cases of intoxication, GSH is depleted and NAPQI accumulates in the organ, causing cell injury and death. The function of NAC is to replenish the stocks of GSH and contribute to a greater supply of oxygen to the injured liver [84,156].

More recently, experts produced an updated evidence-based guide to help clinical practice in the face of episodes of paracetamol poisoning, which is the most common cause of severe acute liver injury in Western countries (Box 2). According to the new guidelines, two bags of NAC administered intravenously $(200 \mathrm{mg} / \mathrm{kg}$ in $4 \mathrm{~h}$, then $100 \mathrm{mg} / \mathrm{kg}$ in $16 \mathrm{~h}$ ) has a similar efficacy to the previous recommended dosage (of three bags), with the advantage of significantly reducing adverse reactions. The protocol also established a weight limit of $110 \mathrm{~kg}$, with a maximum dosage of intravenous NAC equivalent to $22 \mathrm{~g}$ in the first infusion and $11 \mathrm{~g}$ in the second [82].

Box 2. Current recommendation for the treatment of paracetamol poisoning.

Management of paracetamol poisoning New recommendation for standard regimen of two acetylcysteine bags ${ }^{a b}$

Initial infusion

- $\quad \mathrm{NAC} 200 \mathrm{mg} / \mathrm{kg}$ (maximum $22 \mathrm{~g}$ ) in glucose $5 \% 500 \mathrm{~mL}$ (child, $7 \mathrm{~mL} / \mathrm{kg}$ up to $500 \mathrm{~mL}$ ) or sodium chloride $0.9 \% 500 \mathrm{~mL}$ (child, $7 \mathrm{~mL} / \mathrm{kg}$ up to $500 \mathrm{~mL}$ ) intravenously, over $4 \mathrm{~h}$.

Second NAC infusion

- $\quad$ NAC $100 \mathrm{mg} / \mathrm{kg}$ (maximum $11 \mathrm{~g}$ ) in glucose $5 \% 1000 \mathrm{~mL}$ (child, $14 \mathrm{~mL} / \mathrm{kg}$ up to $1000 \mathrm{~mL}$ ) or sodium chloride $0.9 \% 1000 \mathrm{~mL}$ (child, $14 \mathrm{~mL} / \mathrm{kg}$ up to $1000 \mathrm{~mL}$ ) intravenously, over $16 \mathrm{~h}^{\mathrm{b}}$.

If ongoing NAC is required, continue at the rate of the second infusion (i.e., $100 \mathrm{mg} / \mathrm{kg}$ over $16 \mathrm{~h}$ ). Higher ongoing infusion rates (i.e., $200 \mathrm{mg} / \mathrm{kg}$ over $16 \mathrm{~h}$ ) may be required for massive paracetamol ingestions and a clinical toxicologist should be consulted ${ }^{\mathrm{c}}$.

${ }^{a}$ NAC is also compatible with $0.45 \%$ saline $+5 \%$ dextrose. ${ }^{b}$ For adults (aged $\geq 14$ years), dosing should be based on actual body weight rounded up to the nearest $10 \mathrm{~kg}$, with a ceiling weight of $110 \mathrm{~kg}$. For children (aged $<14$ years), actual body weight should be used. ${ }^{\mathrm{c}}$ If the initial paracetamol concentration was more than double the nomogram line following an acute ingestion, acetylcysteine dose should be increased to $200 \mathrm{mg} / \mathrm{kg}$ (maximum $22 \mathrm{~g}$ ) in glucose $5 \% 1000 \mathrm{~mL}$ (child, $14 \mathrm{~mL} / \mathrm{kg}$ up to $1000 \mathrm{~mL}$ ) or sodium chloride $0.9 \%$ $1000 \mathrm{~mL}$ (child, $14 \mathrm{~mL} / \mathrm{kg}$ up to $1000 \mathrm{~mL}$ ) intravenously, over $16 \mathrm{~h}$. Adapted from Chiew et al. (2020) [82] 
Like paracetamol poisoning, other drugs and herbal or dietary supplements can also cause acute or chronic liver damage. Liver damage induced by non-paracetamol drugs also includes direct, immune-mediated, and mitochondrial cell damage; however, the mechanism underlying hepatotoxicity does not involve GSH depletion and remains unclear $[83,84]$. Even so, it is suspected that NAC has beneficial effects in this situation by optimizing the oxygen supply and improving systemic hemodynamics [83].

A prospective study showed a significant improvement in survival of patients with acute liver failure treated with intravenous NAC $(150 \mathrm{mg} / \mathrm{kg}$ over $1 \mathrm{~h}$, followed by $12.5 \mathrm{mg} / \mathrm{kg} / \mathrm{h}$ for $4 \mathrm{~h}$ and continuous infusion of $6.25 \mathrm{mg} / \mathrm{kg} / \mathrm{h}$ for the remaining $67 \mathrm{~h}$ ), with a lower mortality rate and shorter hospital stay [80]. Another study failed to demonstrate a beneficial effect associated with the use of intravenous infusion of NAC for $72 \mathrm{~h}$ in patients with non-paracetamol drug-induced liver injury [81].

The administration of intravenous NAC in patients with acute liver failure not induced by paracetamol shortly after admission reduces mortality and the need for liver transplantation, in addition to reduced encephalopathy, hospitalization, admission to the intensive care unit and failure of other organs [157]. Corroborating these data, a recent meta-analysis also concluded that NAC improves survival, transplant-free survival, posttransplant survival and length of hospital stay for patients with acute liver failure unrelated to paracetamol [158].

Nonalcoholic fatty liver disease (NAFLD) can manifest as simple steatosis or progress to chronic liver damage, due to the increased hepatic flow of free fatty acids, which generates an increase in oxidative stress concomitant with the suppression of intracellular antioxidant activity. Evidence from experimental studies has revealed that NAC blocks the accumulation of liver lipids and reduces proinflammatory markers, such as IL- 6 and IL- $1 \beta$, TNF- $\alpha$, and NF-KB [159].

Clinical studies that analyze NAC supplementation in the liver function of patients with NAFLD are still limited. Khoshbaten et al. (2010) [85] demonstrated that oral administration of NAC ( $600 \mathrm{mg}$ for $12 \mathrm{~h}$ ) for 3 months resulted in decreased levels of alanine transaminase and spleen size in the group treated with NAC compared to patients receiving vitamin C. The study suggests that the decrease in fatty infiltration may be related to the reduction of the spleen and that the longer follow-up of these individuals could bring better results.

In alcoholic liver disease, treatment with oral prednisolone for 28 days combined with intravenous infusions of NAC for 5 days (day 1: at doses of 150, 50, and $100 \mathrm{mg} / \mathrm{kg}$ in 250,500 , and $1000 \mathrm{~mL}$ of solution of $5 \%$ glucose over a period of $30 \mathrm{~min}, 4 \mathrm{~h}$ and $16 \mathrm{~h}$, respectively; days 2 to $5: 100 \mathrm{mg} / \mathrm{kg}$ per day in $1000 \mathrm{~mL}$ of $5 \%$ glucose solution) did not improve patient survival at 6 months, but an improvement in survival at 1 month was evidenced among patients with severe acute alcoholic hepatitis combination therapy, compared to those who received prednisolone alone [86]. Another study also failed to demonstrate the benefit of using high doses $(300 \mathrm{mg} / \mathrm{kg}$ of NAC, diluted in $5 \%$ glucose adjusted to $500 \mathrm{~mL} /$ day) of intravenous NAC associated with enteral nutritional support in patients with severe acute alcoholic hepatitis [87]. In this sense, more clinical trials are needed for clarifying the potential effects of NAC on hepatic involvement.

\subsection{Kidney Diseases}

Acute kidney injury is a frequent manifestation in patients after cardiac surgery, in which it presents multifactorial pathophysiology that includes especially hemodynamic factors, nephrotoxic drugs, and inflammation. Therefore, NAC is used as an alternative perioperative therapy in an attempt to reduce the risk of acute kidney injury associated with surgery $[160,161]$. In meta-analysis, it was found that the intravenous administration of NAC ( $150 \mathrm{mg} / \mathrm{kg}$ to $1200 \mathrm{mg}$ ) in chronic renal patients undergoing cardiac surgery was able to significantly reduce the incidence of acute kidney injury and adverse cardiac events [88]. However, in another systematic review with meta-analysis, aiming to assess whether perioperative administration of NAC reduces the risk of acute kidney injury 
associated with cardiac surgery, similar rates were observed in the occurrence of the risk of acute kidney injury associated with cardiac surgery, changes in creatinine serum, and hospital mortality rate, in both groups. Thus, the authors concluded that perioperative administration of NAC is not recommended as an alternative to reduce the risk of acute kidney injury associated with cardiac surgery [162].

On the other hand, in patients with chronic kidney disease in stage 5 , the administration of $5000 \mathrm{mg}$ of NAC in 5\% glucose in a final volume of $50 \mathrm{~mL}$, intravenously during the hemodialysis session, was sufficient to significantly improve vascular reactivity pressure during reactive hyperemia [89]. In addition, when evaluated in patients with stage 3 chronic kidney disease, $600 \mathrm{mg}$ oral NAC supplementation was not able to alter serum creatinine or cystatin C [90].

Lastly, there is no current consensus/guidelines established on the use or not of NAC in patients diagnosed with kidney disease, due to the quality of the studies, standardization of doses, and determination of the ideal method of administration.4.7. Gastrointestinal Diseases.

\subsection{Gastrointestinal Diseases}

Gastrointestinal diseases are frequent, and their treatment represents a great challenge today. Therefore, given its ability to act as an antioxidant, during the processes of stress, infection, and inflammation, NAC has been widely used in different gastrointestinal clinical conditions, including in cases of infection by Helicobacter pylori, colon cancer, and inflammatory bowel diseases (IBDs).

Helicobacter pylori infection is one of the most frequent infections worldwide, being closely related to environmental, behavioral, and genetic factors $[163,164]$. Upon colonization, the bacteria initiate a local inflammatory response by breaking the mucous barrier and adhering to the gastric epithelium, producing nitric oxide and reactive oxygen species (ROS) [165]. Once persistent, inflammation can lead to pathologies such as chronic gastritis, gastric cancer, and peptic ulcer [166-168].

Thus, in an attempt at adjuvant treatment to antibiotics, NAC is gradually being used, whereas studies indicate that this drug may have a mechanism to prevent the formation and/or destruction of biofilms, formed by the bacteria as a way of survival in the acidic environment and protection against the action of antibiotics, in addition to reducing oxidative stress and inflammatory activity of the gastric mucosa caused by the toxins of Helicobacter pylori $[169,170]$.

Thus, studies have suggested that the addition of NAC to different antibiotic regimens may increase the rate of eradication of the bacterium, when compared to therapies without NAC supplementation [91,92]. Therefore, reinforcing this assumption, it was observed that NAC may have a favorable effect in decreasing bacterial colonization and in preventing gastritis in individuals with initial or mild infection by Helicobacter pylori, in which these effects were reported after administration of NAC associated with conventional antibiotic therapy, within 6 weeks [171].

However, as described in a systematic review, there is a lack of standards and details of the results of the few randomized clinical trials performed, which hinders the accuracy of information regarding the safety and efficacy of the applicability of NAC associated with the use of antibiotics in Helicobacter pylori-infected individuals [172]. Supporting the findings of this meta-analysis, a later study that aimed to assess the use of NAC associated with first-line triple therapy did not report an additive effect on the rate of eradication of the bacterium, when associated with the two therapeutic regimens [173].

In relation to colon cancer, evidence has pointed to the possible protective role of NAC against the oxidative damage common to cancer cells, where long-term ( $>7$ days) drug management with NAC is able to protect the colon mucosa and reduce the occurrence of colon cancer, associated with colitis, by reducing the damage provoked by nitrotyrosine and 8-oxoG [93]. Likewise, the effect of administering NAC in patients with gastrointestinal cancer who underwent major abdominal surgery was assessed, whereby offering $1200 \mathrm{mg}$ / day of NAC, via schematic parenteral nutrition 2 days before surgery until 5 days 
postoperatively, was able to reduce MDA and urinary nitrate, as well as improve the ratio of reduced to oxidized glutathione (GSH/GSSG) [94]. Likewise, in a randomized clinical trial, the chemopreventive action of NAC ( $800 \mathrm{mg} /$ day) was identified as an agent in colon cancer, by reducing the hyperproliferation of the colonic epithelium [95].

In addition, IBDs with their inflammatory and oxidative status can benefit from the administration of NAC, in view of the replenishment of the GSH pool and increasing the GSH/GSSG ratio. Therefore, in research with patients diagnosed with Crohn's disease, NAC was able to suppress the secretion of metalloproteinase- 2 and metalloproteinase- 3 (which, when elevated, are directly related to the severity of the disease and may contribute to the alteration of the epithelial barrier), in addition to exerting a direct effect on its activity when secreted, by increasing the GSH/GSSG ratio [174,175]. Likewise, treatment in patients with ulcerative colitis has shown significant improvement in clinical parameters (stool frequency and consistency, nocturnal stools, visible blood in stool, fecal incontinence, abdominal pain, abdominal tenderness, and need for antidiarrheals, evaluated by the Modified Truelove-Witts Severity Index) and a reduction in serum proinflammatory cytokines [96].

Furthermore, evidence suggests that NAC supplementation, when performed correctly, may be able to improve distal intestinal obstruction syndrome, especially in older individuals; however, more studies need to be performed in order to assess dose, route of administration, and safety [176,177].

When damaged, the intestinal barrier can be directly associated with diseases such as bacterial infections, autoimmune diseases, and systemic inflammation. Thus, NAC can play a role in restoring the intestinal barrier by deactivating protein kinases activated by mitogens and cellular Src (c-Src), which, in conditions of inflammation, are responsible for inducing the dissociation of the intestinal junctions and, therefore, compromising the intestinal barrier [178].

Therefore, although the results are promising, there are still controversies, where, in some cases, NAC does not have enough evidence to be used, thus requiring more robust and reliable studies.

\subsection{Infectious Diseases}

NAC has a range of identified therapeutic potential applications, notably the treatment of various infectious diseases, by attenuating mediators of oxidative stress and inflammation. In terms of improvement effects with NAC, evidence by Wang et al. (2008) [97] showed that its supplementation ( $8000 \mathrm{mg} /$ day) was able to decrease total bilirubin and aminotransferases and increase prothrombin activity in patients diagnosed with severe chronic hepatitis B. Likewise, when the effect of the drug was evaluated in patients with acute viral hepatitis, an improvement in transplant-free survival and a reduction in mortality were observed $[157,179]$.

From this perspective, in addition to its antioxidant activity, NAC was able to increase antimycobacterial activity in human macrophages infected with Mycobacterium tuberculosis [180]. Accordingly, patients diagnosed with pulmonary tuberculosis supplemented with NAC (600 mg/day) had significantly reduced sputum, as well as improved radiological response, serum glutathione peroxidase level, and immune response [98].

New studies are being carried out in an attempt to assess the effects of NAC in patients affected by SARS-CoV-2, whether preventively and/or as an adjuvant. Thus, it is believed that NAC would be able to block the exacerbated production of the angiotensin IIconverting enzyme, limiting the penetration of the virus into cells, as well as participate in oxidative stress and inflammation (especially in inhibiting NF-kB activation), mechanisms that would possibly reduce the severity of lung disease in these patients [181-183]. Currently, a clinical trial is being carried out with patients supplemented with $6000 \mathrm{mg} /$ day of NAC associated with therapies prescribed for COVID-19, which aims to quantify the number of patients accurately extubated and/or transferred from the intensive care unit (ICU) and the number of patients discharged due to clinical progress (ID NCT04374461) [99]. 
Nevertheless, in a phase III controlled randomized clinical trial with patients diagnosed with severe COVID-19, supplementation of intravenous NAC associated with standard treatment is being carried out, where the authors believe that, in addition to exerting a mucolytic effect, NAC will be able to help in patient recovery through its antioxidant effects (IRCT20200509047364N3, at Iranian Registry of clinical trials) [184].

Chorioamnionitis is a common complication of pregnancy, characterized by acute inflammation of the amniotic and chorionic membranes due to a bacterial infection. It is associated with significant brain injury in newborns, periventricular leukomalacia, and cerebral palsy, related to cytokine storm and oxidative stress, which are characteristic conditions of the disease $[100,185]$. Considering the potential of NAC as a fetal and neonatal neuroprotective, a prospective, double-blind study conducted with the motherchild binomial during pregnancy and postpartum (11 mothers and 12 newborns) evaluated the pharmacokinetics (PK) of intravenous NAC in pregnant women with chorioamnionitis and their children, in addition to placental transfer. The study showed that NAC clearance is faster in pregnant women than in nonpregnant women. Placental transfer of NAC was also rapid and the rate of fetal clearance was slower, indicating that NAC has a prenatal therapeutic potential for these newborns at high risk of brain inflammation [100].

The same research group in a prospective double-blind study with 22 pregnant women with a clinical diagnosis of chorioamnionitis and 24 newborns (including two pairs of twins) sought to assess the safety of NAC in the pre- and postnatal maternal and child group. The study treated women before delivery with NAC $(100 \mathrm{mg} / \mathrm{kg} /$ dose $)$ or saline, administered intravenously every $6 \mathrm{~h}$ until birth. The newborns in the treated group received NAC (preterm: $12.5 \mathrm{mg} / \mathrm{kg} /$ dose; term: $25 \mathrm{mg} / \mathrm{kg} /$ dose) $6 \mathrm{~h}$ after the mother's last dose and every $12 \mathrm{~h}$ for five doses. The study demonstrated an absence of significant adverse effects, with beneficial results for mother and child. In treated newborns, NAC restored normal cerebrovascular coupling between major brain vessels, reduced the proinflammatory vascular endothelial growth factor (VEGF), and increased the anti-inflammatory cytokine IL-1 receptor antagonist (IL-1Ra). Treated women also demonstrated lower levels of cytokines associated with endothelial activation and leukocyte recruitment in inflammation [185].

Another placebo-controlled clinical trial was carried out with 67 pregnant women at risk of preterm delivery due to the diagnosis of infection and/or intrauterine inflammation (Triple I), which is an important cause of adverse outcomes in newborns, including premature delivery. The pregnant women followed the following protocol: infusion of a loading dose of NAC $(150 \mathrm{mg} / \mathrm{kg})$ administered in $1 \mathrm{~h}$, followed by continuous infusion of NAC $(50 \mathrm{mg} / \mathrm{kg})$ for $4 \mathrm{~h}$, and infusion of $100 \mathrm{mg} / \mathrm{kg}$ of NAC in the next $16 \mathrm{~h}$ or until delivery versus infusion of dextrose (5\%) in water (D5W) in the placebo group. The study showed that maternal intrapartum NAC infusion is feasible, safe, and effective in reducing the mortality rate and severe neonatal morbidity, such as bronchopulmonary dysplasia, in addition to improving Apgar scores at 1 and $5 \mathrm{~min}$ and reducing the need for resuscitation with positive pressure ventilation [101].

In children under 15 years of age, NAC was used in a placebo-controlled clinical trial as a therapeutic proposal for acute pyelonephritis, which is a kidney infection, usually caused by bacteria that cause urinary tract infections. The children received NAC orally for 5 days, according to their weight, in the following scheme: children with a body weight equal to or greater than $30 \mathrm{~kg}, 900 \mathrm{mg} /$ day; children weighing between 8.5 and $30 \mathrm{~kg}$, $600 \mathrm{mg} /$ day; children weighing less than $8.5 \mathrm{~kg}, 70 \mathrm{mg} / \mathrm{kg} /$ day. The study did not demonstrate any benefits associated with the use of NAC in these patients. The authors suggested that the short period of administration of NAC is not able to cause reductions in inflammatory biomarkers present in this condition [102].

\subsection{Cancer Prevention and Treatment}

With its important pharmacological and biological activities, NAC has been investigated as an agent in the prevention and treatment of some types of cancer. Therefore, NAC was widely researched as an anticancer agent, for reducing cancer hostility, increas- 
ing the apoptosis of cancer cells, and reducing catabolism, mitochondrial dysfunction, inflammatory mediators, and oxidative stress [46].

Oxidative stress causes a glycolytic and catabolic state in the stromal tumor cells, in which catabolites are released, such as lactate [186], which in turn support mitochondrial metabolism in carcinoma cells through metabolic heterogeneity. Thus, this heterogeneity increases the proliferation of cancer cells, reduces apoptosis, and stimulates larger tumors with metastases $[187,188]$.

Won et al. (2020) [103] developed a prospective, controlled multicenter study to assess whether inhalation therapy with NAC would improve the quality of life of patients undergoing radiation therapy. The participants were patients with head and neck cancer identified in 10 institutions, where the experimental group inhaled $2400 \mathrm{mg}$ per day nebulized liquid NAC, for a period of 8 weeks from the beginning of radiotherapy. This study found no adverse effects associated with drug inhalation, and the main finding was an improvement in the patients' quality of life, as there was a greater reduction in the use of analgesics up to one month after therapy in the experimental group when compared to the control group $(p=0.014)$. Nevertheless, symptoms such as xerostomia were significantly improved in the experimental group $(p=0.019)$ [103]; similar data were also confirmed in a randomized clinical trial, in which patients who underwent mouth rinsing with $2500 \mathrm{mg}$ /day of NAC before and after radiotherapy had an improvement in saliva thickening and xerostomia [104].

A randomized clinical trial with patients detected with head and neck cancer revealed that transtympanic injections with NAC were able to prevent cisplatin-induced ototoxicity when applied before exposure, admitting that this protective effect is a response to NAC binding with the molecules of cisplatin, capturing free radicals [189].

Oxidative stress induces the expression of the stromal monocarboxylate transporter 4 (MCT4), a marker of catabolism frequently elevated in breast cancer, suggesting the transport of cancer-associated stromal catabolites to highly proliferative cancer cells. Therefore, as NAC tends to prefer cells with altered glucose, it is understood that cells with a high concentration of MCT4 would be more susceptible to the effects of the drug. Thus, a pilot study exposed that NAC expressed safety and biological activity in breast cancer, where it reduced the proliferation of cells and the expression of MCT4 [190].

Nevertheless, the identification of gastric cancer in early stages is extremely important for effective treatment and reduction of mortality. Thus, it was attested that NAC in an adjuvant way to other drugs can assist in this identification, where its efficacy and costeffectiveness were proven as premedication during examination of upper gastrointestinal endoscopy, since it acts directly by breaking the links between the molecules and assisting in the elimination of mucus, limiting one of the obstacles in this type of exam, which is the high presence of this content on the mucosal surface [191,192].

In summary, according to several studies, NAC supplementation can reduce the proliferation, migration, and invasion of cancer cells in different types of cancer [193,194]. Thus, NAC remains a promising strategy for future therapies in the treatment and prevention of cancers.

\subsection{Other Conditions}

In addition to the situations described above, NAC can be used in situations such as substance abuse disorders, autism spectrum disorder, dermatological diseases (type I lamellar ichthyosis, bullous morphea, systemic sclerosis, toxic epidermal necrolysis, atopic dermatitis, acne), wound healing, insulin resistance, pre-eclampsia, and sickle cell anemia, among others [195].

Commonly, studies have indicated that NAC acts as a promising agent for the treatment of substance use disorders, whereas the drug has the ability to restore the transmission of the prefrontal glutamate from the nucleus accumbens, reducing relapses. Furthermore, a randomized clinical trial examining the efficacy of NAC, in adjuvant treatment for smoking cessation, found that NAC $(1800 \mathrm{mg})$ associated with first-line treatment was able to 
significantly reduce exhaled carbon monoxide $(p<0.01)$; the intervention group showed no withdrawal symptoms, depression, or anxiety and had a significant decrease in the levels of the soluble tumor necrosis factor 2 receptor (sTNF-R2) [105].

Additionally, due to its involvement in the extracellular modulation of glutamate, NAC becomes plausible in the treatment of autism spectrum disorder, since glutamatergic dysfunction and oxidative stress seem to be linked to the disease. Therefore, a systematic review with meta-analysis assessed that NAC supplementation allowed a significant reduction in hyperactivity and irritability, as well as increased social awareness in children with autism spectrum disorder. However, the authors recommended that more studies need to be carried out to have an effective NAC recommendation [196].

Regarding male fertility, NAC has positive effects on spermatogenesis and testicular function, which are well understood, which allows recommending this drug in the treatment of diseases induced by oxidative stress in the male reproductive system [197]. Randomized clinical trials with 50 infertile men with asthenoteratozoospermia showed that $600 \mathrm{mg} /$ day of oral NAC for 3 months significantly improved sperm count, motility, and normal morphology [106].

NAC has also been proposed for the treatment of patients with sickle cell anemia due to the relationship of the disease with the increase in oxidative stress, concomitant with a reduction in antioxidant systems, which includes GSH. A pilot study showed that NAC may be a beneficial therapeutic strategy for sickle cell patients, as oral administration of 1200 or $2400 \mathrm{mg}$ of NAC/day for 6 weeks was able to reduce the expression of phosphatidylserine in the erythrocyte membrane, which is a marker of oxidative stress [107]. Another phase II double-blind randomized clinical trial also showed that the administration of oral NAC up to $2400 \mathrm{mg}$ /day is well tolerated by patients with sickle cell anemia or thalassemia, producing beneficial effects such as the inhibition of dense cells, restoration of levels of GSH, and reduction in the number of vaso-occlusive episodes [108]. On the other hand, Sins et al. (2016) [198] failed to demonstrate positive effects of NAC treatment in patients with sickle cell disease compared to placebo. However, the authors claim a low adherence rate among participants that may have compromised the results of the survey.

As for pre-eclampsia, only two studies are described in the literature evaluating the supplementation of NAC in humans, where one identified an effect of increasing weight at birth and Apgar score [109], while the other found stabilizing effects of the disease in women with the severe form of early-onset disease and/or HELLP syndrome (hemolysis, elevated liver enzymes, low platelets) [110].

For gestational diabetes, clinical trials are not yet available. However, an experimental study with female mice with pregestational diabetes showed that administration of NAC during pregnancy was able to increase GSH levels, reduce ROS levels in the fetal heart, and prevent the development of congenital heart defects in the offspring of diabetes. Thus, the study suggested that the use of NAC may be a potential strategy (alone or combined with insulin) to prevent congenital heart defects in newborns of diabetic mothers [199]. From this perspective, a clinical trial that aims to analyze the results of pregnancy and the metabolic profile of women with gestational diabetes mellitus supplemented with oral NAC (600 mg/three times daily/for 6 weeks) is registered in the Cochrane Central Register of Controlled Trials (ID CN-02170464).

Although the current data are considered preliminary and there are few randomized clinical trials on the involvement of NAC in these pathologies, this drug can be a viable option in the treatment or act in an adjuvant way [200].

A pilot study with 35 patients diagnosed with metabolic syndrome evaluated the efficacy of NAC, where tablets containing $600 \mathrm{mg}$ were administered twice daily for a period of 6 weeks. As a result, the individuals in the intervention group had insulin resistance parameters estimated by the homeostatic assessment model (HOMA-IR), highly sensitive C-reactive proteins (hsCRP), systolic blood pressure, and significantly reduced triglycerides. Thus, NAC can exert several beneficial effects on the disease through antioxidant, antiinflammatory, and vasodilatory routes [111]. 
Nevertheless, NAC is used in some ocular conditions, for example, in cases of dysfunction of the meibomian gland, a type of blepharitis (inflammatory disease associated with itching, redness, and flaking and crusting of the eyelids), in which it generates ocular dryness. Therefore, Akyol-Salman et al. (2010) [113], in a clinical trial, evaluated the use of $5 \%$ NAC in the form of eye drops in patients with this manifestation, where, after 1 month of therapy, the individuals had significant improvements in itching, eye burning, foreign body sensation, and blurred vision. In another clinical trial, comparing the topical use of NAC with the use of the combination of steroid-antibiotic betamethasone-sodium sulfacetamide therapy, it was observed that, in conjunction with the hygiene of the eyelids, the administration of NAC appears to be as effective as a topical steroid-antibiotic combination, in patients with meibomian gland dysfunction [114]. In addition, a randomized clinical trial identified a significant effect after oral administration of $100 \mathrm{mg} /$ day of NAC in patients with chronic blepharitis, where the authors described that the finding was due to the effect of NAC in blocking lipid peroxidation in this disease [112]. When compared to the use of artificial tears, topical formulations of NAC for $5 \%$ in patients undergoing dry eye treatment administered four times a day for 2 weeks was able to cause improvements in the reported symptoms [201].

\section{Conclusions}

NAC acts as a precursor to intracellular cysteine, increasing the pool of GSH, which in turn is essential in several diseases linked to oxidative stress as a consequence of glutathione depletion. Thus, although NAC is used in a range of diseases, further studies are needed with a view to clarifying adequate dosages and treatment protocols, aiming at an efficient and wide performance of NAC in the treatment of different pathologies.

Author Contributions: Conceptualization, A.C.M.d.O. and M.O.F.G.; methodology, A.C.M.d.O. and M.O.F.G.; investigation, M.C.d.S.T., N.G.G., F.A.M., A.C.M.d.O. and M.O.F.G.; data curation, F.A.M., A.C.M.d.O. and M.O.F.G. writing—original draft preparation, M.C.d.S.T., N.G.G., F.A.M., A.C.M.d.O. and M.O.F.G.; writing-review and editing, M.C.d.S.T., N.G.G., F.A.M., A.C.M.d.O. and M.O.F.G.; visualization, F.A.M., A.C.M.d.O. and M.O.F.G.; supervision, F.A.M., A.C.M.d.O. and M.O.F.G. All authors have read and agreed to the published version of the manuscript.

Funding: The authors gratefully acknowledge the financial support of the Brazilian research funding agencies CNPq (for fellowships to M.C.d.S.T, N.G.G., and M.O.F.G.), CAPES/RENORBIO/PROAP, INCT-Bioanalítica, and FAPEAL/PPSUS, project 60030.0000000192/2021.

Conflicts of Interest: The authors declare no conflict of interest.

\section{References}

1. Tardiolo, G.; Bramanti, P.; Mazzon, E. Overview on the effects of n-acetylcysteine in neurodegenerative diseases. Molecules 2018, 23, 3305. [CrossRef]

2. Ooi, S.L.; Green, R.; Pak, S.C. N-Acetylcysteine for the treatment of psychiatric disorders: A review of current evidence. BioMed Res. Int. 2018, 2018, 8. [CrossRef]

3. Aldini, G.; Altomare, A.; Baron, G.; Vistoli, G.; Carini, M.; Borsani, L.; Sergio, F. N-Acetylcysteine as an antioxidant and disulphide breaking agent: The reasons why. Free Radic. Res. 2018, 52, 751-762. [CrossRef]

4. Dodd, S.; Dean, O.; Copolov, D.L.; Malhi, G.S.; Berk, M. N-acetylcysteine for antioxidant therapy: Pharmacology and clinical utility. Expert Opin. Biol. Ther. 2008, 8, 1955-1962. [CrossRef]

5. $\quad$ Ezerina, D.; Takano, Y.; Hanaoka, K.; Urano, Y.; Dick, T.P. N-Acetyl cysteine functions as a fast-acting antioxidant by triggering intracellular h2s and sulfane sulfur production. Cell Chem. Biol. 2018, 25, 447-459. [CrossRef] [PubMed]

6. Cuzzocrea, S.; Mazzon, E.; Costantino, G.; Serraino, I.; Dugo, L.; Calabrò, G.; Cucinotta, G.; De Sarro, A.; Caputi, A.P. Beneficial effects of n-acetylcysteine on ischaemic brain injury. Br. J. Pharmacol. 2000, 130, 1219-1226. [CrossRef] [PubMed]

7. Crupi, R.; Gugliandolo, E.; Siracusa, R.; Impellizzeri, D.; Cordaro, M.; Di Paola, R.; Britti, D.; Cuzzocrea, S. N-acetyl-L-cysteine reduces Leishmania amazonensis-induced inflammation in BALB/c mice. BMC Vet. Res. 2020, 16, 13. [CrossRef] [PubMed]

8. Poncin, S.; Colin, I.M.; Decallonne, B.; Clinckspooor, I.; Many, M.C.; Denef, J.F.; Gérard, A.C. N-acetylcysteine and 15 deoxy\{delta\}12,14-prostaglandin J2 exert a protective effect against autoimmune thyroid destruction in vivo but not against interleukin1 \{alpha\}/interferon \{gamma\}-induced inhibitory effects in thyrocytes in vitro. Am. J. Pathol. 2010, 177, 219-228. [CrossRef] [PubMed] 
9. De Andrade, K.Q.; Moura, F.A.; Dos Santos, J.M.; De Araújo, O.R.; De Farias Santos, J.C.; Goulart, M.O.F. Oxidative stress and inflammation in hepatic diseases: Therapeutic possibilities of N-Acetylcysteine. Int. J. Mol. Sci. 2015, 16, 30269-30308. [CrossRef]

10. Shahripour, R.B.; Harrigan, M.R.; Alexandrov, A.V. N-acetylcysteine (NAC) in neurological disorders: Mechanisms of action and therapeutic opportunities. Brain Behav. 2014, 4, 108-122. [CrossRef]

11. Rushworth, G.F.; Megson, I.L. Existing and potential therapeutic uses for N-acetylcysteine: The need for conversion to intracellular glutathione for antioxidant benefits. Pharmacol. Ther. 2014, 141, 150-159. [CrossRef] [PubMed]

12. Holdiness, M.R. Clinical pharmacokinetics of N-Acetylcysteine. Clin. Pharmacokinet. 1991, 20, 123-134. [CrossRef] [PubMed]

13. Borgstrom, L.; Kagedal, B.; Paulsen, O. Pharmacokinetics of N-acetylcysteine in man. Eur. J. Clin. Pharmacol. 1986, 31, 217-222. [CrossRef] [PubMed]

14. Olsson, B.; Johansson, M.; Gabrielsson, J.; Bolme, P. Pharmacokinetics and bioavailability of reduced and oxidized N-acetylcysteine. Eur. J. Clin. Pharmacol. 1988, 34, 77-82. [CrossRef]

15. Jones, A.L.; Jarvie, D.R.; Simpson, D.; Hayes, P.C.; Prescott, L.F. Pharmacokinetics of N-acetylcysteine are altered in patients with chronic liver disease. Aliment. Pharmacol. Ther. 1997, 11, 787-791. [CrossRef]

16. Villeneuve, E.; Gosselin, S. N-Acetylcysteine. In Critical Care Toxicology; Brent, J., Burkhart, K., Dargan, P., Hatten, B., Megarbane, B., Palmer, R., White, J., Eds.; Springer: Berlin/Heidelberg, Germany, 2017.

17. Prescott, L.F.; Donovan, J.W.; Jarvie, D.R.; Proudfoot, A.T. The disposition and kinetics of intravenous N-acetylcysteine in patients with paracetamol overdosage. Eur. J. Clin. Pharmacol. 1989, 37, 501-506. [CrossRef]

18. Nolin, T.D.; Ouseph, R.; Himmelfarb, J.; McMenamin, M.E.; Ward, R.A. Multiple-dose pharmacokinetics and pharmacodynamics of n-acetylcysteine in patients with end-stage renal disease. Clin. J. Am. Soc. Nephrol. 2010, 5, 1588-1594. [CrossRef] [PubMed]

19. Bonanomi, L.; Gazzaniga, A. Toxicological, pharmacokinetic and metabolic studies on acetylcysteine. Eur. J. Respir. Dis. Suppl. 1980, 111, 45-51.

20. Rodenstein, D.; De Coster, A.; Gazzaniga, A. Pharmacokinetics of oral acetylcysteine. Clin. Pharmacokinet. 1978, 3, 247-254. [CrossRef]

21. Papi, A.; Di Stefano, A.F.D.; Radicioni, M. Pharmacokinetics and safety of single and multiple doses of oral n-acetylcysteine in healthy chinese and caucasian volunteers: An open-label, phase i clinical study. Adv. Ther. 2021, 38, 468-478. [CrossRef]

22. Toxicology Investigator Network. A multicenter comparison of the safety of oral versus intravenous acetylcysteine for treatment of acetaminophen overdose. Clin. Toxicol. 2010, 48, 424-430. [CrossRef] [PubMed]

23. Greene, S.C.; Noonan, P.K.; Sanabria, C.; Peacock, W.F. Effervescent N-Acetylcysteine tablets versus oral solution n-acetylcysteine in fasting healthy adults: An open-label, randomized, single-dose, crossover, relative bioavailability study. Curr. Ther. Res. 2016, 83, 1-7. [CrossRef] [PubMed]

24. Yarema, M.; Chopra, P.; Sivilotti, M.L.A.; Johnson, D.; Nettel-Aguirre, A.; Bailey, B.; Victorino, C.; Gosselin, S.; Purssell, R.; Thompson, M.; et al. Anaphylactoid reactions to intravenous n-acetylcysteine during treatment for acetaminophen poisoning. $J$. Med. Toxicol. 2018, 14, 120-127. [CrossRef]

25. Homma, S.; Azuma, A.; Taniguiche, H.; Ogura, T.; Mochiuki, Y.; Sugiyama, Y.; Nakata, K.; Yoshimura, K.; Takeuchi, M.; Kudoh, S. Efficacy of inhaled $\mathrm{N}$-acetylcysteine monotherapy in patients with early stage idiopathic pulmonary fibrosis. Respirology 2012, 17, 467-477. [CrossRef] [PubMed]

26. Kuzmenko, N.; Oleg, I.; Dmytro, D.; Roman, I.; Galyna, G. The efficacy and safety of inhaled acetylcysteine in comparison with oral acetylcysteine in chronic obstructive pulmonary disease: A randomized single-center study. Pol. Ann. Medicine. 2020, 27, 108-114. [CrossRef]

27. Calverley, P.; Rogliani, P.; Papi, A. Safety of N-Acetylcysteine at high doses in chronic respiratory diseases: A review. Drug Saf. 2021, 44, 273-290. [CrossRef] [PubMed]

28. Feng, F.; Zhang, J.; Wang, Z.; Wu, Q.; Zhou, X. Efficacy and safety of N-acetylcysteine therapy for idiopathic pulmonary fibrosis: An updated systematic review and meta-analysis. Exp. Ther. Med. 2019, 18, 802-816. [CrossRef] [PubMed]

29. Liou, G.G.; Hsieh, C.C.; Lee, Y.J.; Li, P.H.; Tsai, M.S.; Li, C.T.; Wang, S.H. N-Acetyl cysteine overdose inducing hepatic steatosis and systemic inflammation in both propacetamol-induced hepatotoxic and normal mice. Antioxidants 2021, 10, 442. [CrossRef]

30. Mahmoudi, G.A.; Astaraki, P.; Mohtashami, A.Z.; Ahadi, M. N-acetylcysteine overdose after acetaminophen poisoning. Int. Med. Case Rep. J. 2015, 8, 65-69. [CrossRef]

31. PubChem [Internet]. Bethesda (MD): National Library of Medicine (US), National Center for Biotechnology Information; 2004-PubChem Compound Summary for CID 12035, Acetylcysteine. Available online: https://pubchem.ncbi.nlm.nih.gov/ compound / Acetylcysteine (accessed on 29 April 2021).

32. Drugbank [Internet]. Available online: https://go.drugbank.com/drugs/DB06151 (accessed on 5 April 2021).

33. Pfaff, A.R.; Beltz, J.; King, E.; Ercal, N. Medicinal thiols: Current status and new perspectives. Mini Rev. Med. Chem. 2020, 20, 513-529. [CrossRef]

34. Samuni, Y.; Goldstein, S.; Dean, O.M.; Berk, M. The chemistry and biological activities of N-acetylcysteine. Biochim. Biophys. Acta. 2013, 1830, 4117-4129. [CrossRef] [PubMed]

35. Radomska-Lesnniewska, D.M.; Skopinski, P. N-acetylcysteine as an anti-oxidant and anti-inflammatory drug and its some clinical applications. Centr. Eur. J. Immunol. 2012, 37, 57-66.

36. Pei, Y.; Liu, H.; Yang, Y.; Yang, Y.; Jiao, Y.; Tay, F.R.; Chen, J. Biological activities and potential oral applications of n-acetylcysteine: Progress and prospects. Oxidative Med. Cell. Longev. 2018, 2018, 1-14. [CrossRef] 
37. Aruoma, O.I.; Halliwell, B.; Hoey, B.M.; Butler, J. The antioxidant action of N-acetylcysteine: Its reaction with hydrogen peroxide, hydroxyl radical, superoxide, and hypochlorous acid. Free Radic. Biol. Med. 1989, 6, 593-597. [CrossRef]

38. Prutz, W.A.; Monig, H.; Butler, J.; Land, E.J. Reactions of nitrogen-dioxide in aqueous model systems-Oxidation of tyrosine units in peptides and proteins. Arch. Biochem. Biophys. 1985, 243, 125-134. [CrossRef]

39. Ford, E.; Hughes, M.N.; Wardman, P. Kinetics of the reactions of nitrogen dioxide with glutathione, cysteine, and uric acid at physiological pH. Free Radic. Biol. Med. 2002, 32, 1314-1323. [CrossRef]

40. Chen, S.N.; Hoffman, M.Z. Effect of $\mathrm{pH}$ on the reactivity of carbonate radicals in aqueous solution. Radiat. Res. 1975, 62, 18-27. [CrossRef]

41. Miranda, K.M.; Paolocci, N.; Katori, T.; Thomas, D.D.; Ford, E.; Bartberger, M.D.; Espey, M.G.; Kass, D.A.; Feelisch, M.; Fukuto, J.M.; et al. A biochemical rationale for the discrete behavior of nitroxyl and nitric oxide in the cardiovascular system. Proc. Natl. Acad. Sci. USA 2003, 100, 9196-9201. [CrossRef] [PubMed]

42. Benrahmoune, M.; Therond, P.; Abedinzadeh, Z. The reaction of superoxide radical with N-acetylcysteine. Free Radic. Biol. Med. 2000, 29, 775-782. [CrossRef]

43. Winterbourn, C.C.; Metodiewa, D. Reactivity of biologically important thiol compounds with superoxide and hydrogen peroxide. Free Radic. Biol. Med. 1999, 27, 322-328. [CrossRef]

44. Trujillo, M.; Radi, R. Peroxynitrite reaction with the reduced and the oxidized forms of lipoic acid: New insights into the reaction of peroxynitrite with thiols. Arch. Biochem. Biophys. 2002, 397, 91-98. [CrossRef]

45. Kasperczyk, S.; Dobrakowski, M.; Kasperczyk, A.; Romuk, E.; Rykaczewska-Czerwińska, M.; Pawlas, N.; Birkner, E. Effect of $\mathrm{N}$-acetylcysteine administration on homocysteine level, oxidative damage to proteins, and levels of iron (Fe) and Fe-related proteins in lead-exposed workers. Toxicol. Ind. Health 2016, 32, 1607-1618. [CrossRef]

46. Dhouib, I.E.; Jallouli, M.; Annabi, A.; Gharbi, N.; Elfazaa, S.; Lasram, M.M. A minireview on N-acetylcysteine: An old drug with new approaches. Life Sci. 2016, 151, 359-363. [CrossRef] [PubMed]

47. Ullian, M.E.; Gelasco, A.K.; Fitzgibbon, W.R.; Beck, C.N.; Morinelli, T.A. N-acetylcysteine decreases angiotensin II receptor binding in vascular smooth muscle cells. J. Am. Soc. Nephrol. 2005, 16, 2346-2353. [CrossRef] [PubMed]

48. Hayakawa, M.; Miyashita, H.; Sakamoto, I.; Kitagawa, M.; Tanaka, H.; Yasuda, H.; Karin, M.; Kikugawa, K. Evidence that reactive oxygen species do not mediate NF-kB activation. EMBO J. 2003, 22, 3356-3366. [CrossRef]

49. Meurer, S.K.; Lahme, B.; Tihaa, L.; Weiskirchen, R.; Gressner, A.M. N-acetyl-L-cysteine suppresses TGF-beta signaling at distinct molecular steps: The biochemical and biological efficacy of a multifunctional, antifibrotic drug. Biochem. Pharmacol. 2005, 70, 1026-1034. [CrossRef] [PubMed]

50. Palacio, J.R.; Markert, U.R.; Martínez, P. Anti-inflammatory properties of N-acetylcysteine on lipopolysaccharide-activated macrophages. Inflamm. Res. 2011, 60, 695-704. [CrossRef]

51. Decramer, M.; Rutten-van, M.M.; Dekhuijzen, P.N.R.; Troosters, T.; van Herwaarden, C.; Pellegrino, R.; van Schayck, C.P.O.; Olivieri, D.; Donno, M.D.; De Backer, W.; et al. Effects of N-acetylcysteine on outcomes in chronic obstructive pulmonary disease (Bronchitis Randomized on NAC Cost-Utility Study, BRONCUS): A randomised placebo-controlled trial. Lancet 2005, 365, 1552-1560. [CrossRef]

52. Schermer, T.; Chavannes, N.; Dekhuijzen, R.; Wouters, E.; Muris, J.; Akkermans, R.; van Schayck, O.; van Weel, C. Fluticasone and $\mathrm{N}$-acetylcysteine in primary care patients with COPD or chronic bronchitis. Respir. Med. 2009, 103, 542-551. [CrossRef]

53. Tse, H.N.; Raiteri, L.; Wong, K.Y.; Yee, K.S.; Ng, L.Y.; Wai, K.Y.; Loo, C.K.; Chan, M.H. High-dose n-acetylcysteine in stable COPD. The 1-year, double-blind, randomized, placebo-controlled HIACE Study. Chest 2013, 144, 106-118. [CrossRef]

54. Zheng, J.P.; Wen, F.Q.; Bai, C.X.; Wan, H.Y.; Kang, J.; Chen, P.; Yao, W.Z.; Ma, L.J.; Li, X.; Raiteri, L.; et al. Twice daily Nacetylcysteine $600 \mathrm{mg}$ for exacerbations of chronic obstructive pulmonary disease (PANTHEON): A randomised, double-blind placebo-controlled trial. Lancet Respiriratory Med. 2014, 2, 187-194. [CrossRef]

55. Johnson, K.; McEvoy, C.E.; Naqvi, S.; Wendt, C.; Reilkoff, R.A.; Wetherbee, E.E.; Nelson, D.; Tirouvanziam, R.; Niewoehner, D.E. High-dose oral $\mathrm{N}$-acetylcysteine fails to improve respiratory health status in patients with chronic obstructive pulmonary disease and chronic bronchitis: A randomized, placebo-controlled trial. Int. J. COPD. 2016, 11, 799-807. [CrossRef]

56. Shen, Y.; Cai, W.; Lei, S.; Zhang, Z. Effect of high/low dose n-acetylcysteine on chronic obstructive pulmonary disease: A systematic review and meta-analysis. COPD 2013, 10, 1-8. [CrossRef] [PubMed]

57. Cazzola, M.; Calzetta, L.; Page, C.; Jardim, J.; Chuchalin, A.G.; Rogliani, P.; Matera, M.G. Influence of N-acetylcysteine on chronic bronchitis or COPD exacerbations: A meta-analysis. Europ. Respir. Rev. 2015, 24, 451-461. [CrossRef] [PubMed]

58. Fowdar, K.; Chen, H.; He, Z.; Zhang, J.; Zhong, X.; Zhang, J.; Li, M.; Bai, J. The effect of N-acetylcysteine on exacerbations of chronic obstructive pulmonary disease: A meta-analysis and systematic review. Heart Lung 2017, 46, 120-128. [CrossRef] [PubMed]

59. Ciofu, O.; Smith, S.; Lykkesfeldt, J. Antioxidant supplementation for lung disease in cystic fibrosis. Cochrane Database Syst. Rev. 2019, 10, CD007020. [CrossRef]

60. Tirouvanziam, R.; Conrad, C.K.; Bottiglieri, T.; Herzenberg, L.A.; Moss, R.B.; Herzenberg, L.A. High-dose oral N-acetylcysteine, a glutathione prodrug, modulates inflammation in cystic fibrosis. Proc. Natl. Acad. Sci. USA 2006, 10, 4628-4633. [CrossRef]

61. Skov, M.; Pressler, T.; Likkesfeldt, J.; Poulsen, H.E.; Jensen, P.O.; Johansen, H.K.; Qvist, T.; Kraemer, D.; Hoiby, N.; Ciofu, O. The effect of short-term, high-dose oral $\mathrm{N}$-acetylcysteine treatment on oxidative stress markers in cystic fibrosis patients with chronic P. aeruginosa infection-A pilot study. J. Cyst. Fibros. 2015, 14, 211-218. [CrossRef] 
62. Rogliani, P.; Calzetta, L.; Cavalli, F.; Matera, M.G.; Cazzola, M. Pirfenidone, nintedanib and N-acetylcysteine for the treatment of idiopathic pulmonary fibrosis: A systematic review and meta-analysis. Pulm. Pharmacol Ther. 2016, 40, 95-103. [CrossRef]

63. Arstall, M.A.; Yang, J.; Stafford, I.; Betts, W.H.; Horowitz, J.D. N-acetylcysteine in combination with nitroglycerin and streptokinase for the treatment of evolving acute myocardial infarction: Safety and biochemical effects. Circulation 1995, 92, $2855-2862$. [CrossRef] [PubMed]

64. Yesilbursa, D.; Serdar, A.; Senturk, T.; Serdar, Z.; Sağ, S.; Cordan, J. Effect of N-acetylcysteine on oxidative stress and ventricular function in patients with myocardial infarction. Heart Vessel. 2006, 21, 33-37. [CrossRef] [PubMed]

65. Pereira, J.E.G.; El Dib, R.; Braz, L.G.; Escudero, J.; Hayes, J.; Johnston, B.C. N-acetylcysteine use among patients undergoing cardiac surgery: A systematic review and meta-analysis of randomized trials. PLoS ONE 2019, 14, e0213862. [CrossRef] [PubMed]

66. Gu, W.J.; Wu, Z.J.; Wang, P.F.; Aung, L.H.H.; Yin, R.X. N-Acetylcysteine supplementation for the prevention of atrial fibrillation after cardiac surgery: A meta-analysis of eight randomized controlled trials. BMC Cardiovasc. Disord. 2012, 12, 1-8. [CrossRef] [PubMed]

67. Ozaydin, M.; Peker, O.; Erdogan, D.; Kapan, S.; Turker, Y.; Varol, E.; Ozguner, F.; Dogan, A.; Ibrisim, E. N-acetylcysteine for the prevention of postoperative atrial fibrillation: A prospective, randomized, placebo-controlled pilot study. Eur. Heart J. 2008, 29, 625-631. [CrossRef] [PubMed]

68. Berk, M.; Copolov, D.; Dean, O.; Lu, K.; Jeavons, S.; Schapkaitz, I.; Anderson-Hunt, M.; Judd, F.; Katz, F.; Katz, P.; et al. N-acetyl cysteine as a glutathione precursor for schizophrenia-a double-blind, randomized, placebo-controlled trial. Biol. Psychiatr. 2008, 64, 361-368. [CrossRef] [PubMed]

69. Sepehrmanesh, Z.; Heidary, M.; Akasheh, N.; Akbari, H.; Heidary, M. Therapeutic effect of adjunctive N-acetyl cysteine (NAC) on symptoms of chronic schizophrenia: A double-blind, randomized clinical trial. Prog. Neuropsychopharmacol. Biol. Psychiatr. 2018, 82, 289-296. [CrossRef]

70. Yolland, C.O.B.; Phillipou, A.; Castle, D.J.; Neill, E.; Hughes, M.E.; Galletly, C.; Smith, Z.M.; Francis, P.S.; Dean, O.M.; Sarris, J.; et al. Improvement of cognitive function in schizophrenia with N-acetylcysteine: A theoretical review. Nutr. Neurosci. 2020, 23, 139-148. [CrossRef]

71. Conus, P.; Seidman, L.J.; Fournier, M.; Xin, L.; Cleusix, M.; Baumann, P.S.; Ferrari, C.; Cousins, A.; Alameda, L.; GholamRezaee, M.; et al. N-acetylcysteine in a double-blind randomized placebo-controlled trial: Toward biomarker-guided treatment in early psychosis. Schizophr. Bull. 2018, 44, 317-327. [CrossRef]

72. Berk, M.; Turner, A.; Malhi, G.S.; Ng, C.H.; Cotton, S.M.; Dodd, S.; Samuni, Y.; Tanious, M.; McAulay, C.; Dowling, N.; et al. A randomised controlled trial of a mitochondrial therapeutic target for bipolar depression: Mitochondrial agents, N-acetylcysteine, and placebo. BMC Med. 2019, 17, 1-11. [CrossRef]

73. Magalhães, P.V.; Dean, O.M.; Bush, A.I.; Copolov, D.L.; Malhi, G.S.; Kohlmann, K.K.; Jeavons, S.; Schapkaitz, I.; AndersonHunt, M.D.; Berk, M. N-acetyl cysteine add-on treatment for bipolar II disorder: A subgroup analysis of a randomized placebocontrolled trial. J. Affect. Disord. 2011, 129, 317-320. [CrossRef]

74. Berk, M.; Dean, O.M.; Cotton, S.M.; Jeavons, S.; Tanious, M.; Kohlmann, K.; Hewitt, K.; Moss, K.; Allwang, C.; Schapkaitz, I.; et al. The efficacy of adjunctive $\mathrm{N}$-acetylcysteine in major depressive disorder: A double-blind, randomized, placebo-controlled trial. $J$. Clin. Psychiatr. 2014, 75, 628-636. [CrossRef]

75. Kishi, T.; Miyake, N.; Okuya, M.; Sakuma, K.; Iwata, N. N-acetylcysteine as an adjunctive treatment for bipolar depression and major depressive disorder: A systematic review and meta-analysis of double-blind, randomized placebo-controlled trials. Psychopharmacology 2020, 237, 3481-3487. [CrossRef]

76. Holmay, M.J.; Terpstra, M.; Coles, L.D.; Mishra, U.; Ahlskog, M.; Oz, G.; Cloyd, J.C.; Tuite, P.J. N-acetylcysteine boosts brain and blood glutathione in gaucher and Parkinson's diseases. Clin. Neuropharmacol. 2013, 36, 103. [CrossRef]

77. Monti, D.A.; Zabrecky, G.; Kremens, D.; Liang, T.W.; Wintering, N.A.; Bazzan, A.J.; Bowens, B.K.; Chervoneva, I.; Intenzo, C.; Newberg, A.B. N-Acetyl cysteine is associated with dopaminergic improvement in Parkinson's disease. Clin. Pharmacol Ther. 2019, 106, 884-890. [CrossRef]

78. Coles, L.D.; Tuite, P.J.; Öz, G.; Mishra, U.R.; Kartha, R.V.; Sullivan, K.M.; Terpstra, M.; Cloyd, J.C. Repeated-dose oral Nacetylcysteine in Parkinson's disease: Pharmacokinetics and effect on brain glutathione and oxidative stress. J. Clin. Pharmacol. 2018, 58, 158-167. [CrossRef]

79. Remington, R.; Lortie, J.J.; Hoffmann, H.; Page, R.; Morrell, C.; Shea, T.B. A nutritional formulation for cognitive performance in mild cognitive impairment: A placebo-controlled trial with an open-label extension. J. Alzheimers Dis. 2015, 48, 591-595. [CrossRef]

80. Krysko, K.M.; Bischof, A.; Nourbakhsh, B.; Henry, R.G.; Revirajan, N.; Manguinao, M.; Nguyen, K.; Akula, A.; Li, Y.; Waubant, E. A pilot study of oxidative pathways in MS fatigue: Randomized trial of N-acetyl cysteine. Ann. Clin. Translat. Neurol. 2021, 8 , 811-824. [CrossRef]

81. Monti, D.A.; Zabrecky, G.; Leist, T.P.; Wintering, N.; Bazzan, A.J.; Zhan, T.; Newberg, A.B. N-acetyl cysteine administration is associated with increased cerebral glucose metabolism in patients with multiple sclerosis: An exploratory study. Front. Neurol. 2020, 11, 88. [CrossRef]

82. Chiew, A.L.; Reith, D.; Pomerleau, A.; Wong, A.; Isoardi, K.Z.; Soderstrom, J.; Buckley, N.A. Updated guidelines for the management of paracetamol poisoning in Australia and New Zealand. Med. J. Aust. 2020, 212, 175-183. [CrossRef] 
83. Nabi, T.; Nabi, S.; Rafiq, N.; Shah, A. Role of N-acetylcysteine treatment in non-acetaminophen-induced acute liver failure: A prospective study. Saudi J. Gastroenterol. 2017, 23, 169-175. [CrossRef]

84. Chughlay, M.F.; Kramer, N.; Spearman, C.W.; Werfalli, M.; Cohen, K. N-acetylcysteine for non-paracetamol drug-induced liver injury: A systematic review. Br. J. Clin. Pharmacol. 2016, 81, 1021-1029. [CrossRef]

85. Khoshbaten, M.; Aliasgarzadeh, A.; Masnadi, K.; Tarzamani, M.K.; Farhang, S.; Babaei, H.; Kiani, J.; Zaare, M.; Najafipoor, F. $\mathrm{N}$-acetylcysteine improves liver function in patients with non-alcoholic fatty liver disease. Hep. Mon. 2010, $10,12-16$.

86. Nguyen-Khac, E.; Thevenot, T.; Piquet, M.A.; Benferhat, S.; Goria, O.; Chatelain, D.; Tramier, B.; Dewaele, F.; Ghrib, S.; Rudler, M.; et al. Glucocorticoids plus N-Acetylcysteine in Severe Alcoholic Hepatitis. N. Engl. J. Med. 2011, 365, 1781-1789. [CrossRef]

87. Moreno, C.; Langlet, P.; Hittelet, A.; Lasser, L.; Degre, D.; Evrard, S.; Colle, I.; Lemmers, A.; Deviere, J.; Le Moine, O. Enteral nutrition with or without $\mathrm{N}$-acetylcysteine in the treatment of severe acute alcoholic hepatitis: A randomized multicenter controlled trial. J. Hepatol. 2010, 53, 1117-1122. [CrossRef] [PubMed]

88. He, G.; Li, Q.; Li, W.; Wang, L.; Yang, J.; Zeng, F. N-Acetylcysteine for preventing of acute kidney injury in chronic kidney disease patients undergoing cardiac surgery: A meta analysis. Heart Surg. Forum 2018, 21, E513-E521. [CrossRef] [PubMed]

89. Wittstock, A.; Burkert, M.; Zidek, W.; Tepel, M.; Scholze, A. N-acetylcysteine improves arterial vascular reactivity in patients with chronic kidney disease. Nephron J. 2009, 12, c184-c189. [CrossRef]

90. Mainra, R.; Gallo, K.; Moist, L. Effect of N-acetylcysteine on renal function in patients with chronic kidney disease. Nephrology 2007, 12, 510-513. [CrossRef] [PubMed]

91. Hamidian, S.M.T.; Aletaha, N.S.; Taslimi, R.; Montazeri, M. An additive effect of oral N-acetylcysteine on eradication of Hlicobacter pylori. J. Pathog. 2015, 2015, 540271. [CrossRef]

92. Yoon, H.; Lee, D.H.; Jang, E.S.; Kim, J.; Shin, C.M.; Park, Y.S.; Hwang, J.H.; Kim, J.W.; Jeong, S.H.; Kim, N. Effects of Nacetylcysteine on first-line sequential therapy for Helicobacter pylori infection: A randomized controlled pilot trial. Gut Liver 2016, 10, 520-525. [CrossRef]

93. Irrazabal, T.; Thakur, B.K.; Croitoru, K.; Martin, A. Preventing colitis-associated colon cancer with antioxidants: A systematic review. Cell. Mol. Gastroenterol. Hepatol. 2021, 11, 1177-1197. [CrossRef]

94. Kuyumcu, A.; Akyol, A.; Buyuktuncer, Z.; Ozmen, M.M.; Besler, H.T. Improved oxidative status in major abdominal surgery patients after $\mathrm{N}$-acetyl cysteine supplementation. Nutr. J. 2015, 14, 1-9. [CrossRef]

95. Estensen, R.D.; Levy, M.; Klopp, S.J.; Galbraith, A.R.; Mandel, J.S.; Blomquist, J.A.; Wattenberg, L.W. N-acetylcysteine suppression of the proliferative index in the colon of patients with previous adenomatous colonic polyps. Cancer Lett. 1999, 147, 109-114. [CrossRef]

96. Guijarro, L.G.; Mate, J.; Gisbert, J.P.; Perez-Calle, J.L.; Marin-Jimenez, I.; Arriaza, E.; Olleros, T.; Delgado, M.; Castillejo, M.S.; Prieto-Merino, D.; et al. N-acetyl-L-cysteine combined with mesalamine in the treatment of ulcerative colitis: Randomized, placebo-controlled pilot study. World J. Gastroenterol. 2008, 14, 2851-2857. [CrossRef]

97. Wang, N.; Shi, X.F.; Guo, S.H.; Zhang, D.Z.; Ren, H. A clinical study of N-acetylcysteine treatment in chronic hepatitis B patients. Zhonghua Gan Zang Bing Za Zhi. Chin. J. Hepatol. 2008, 16, 487-489.

98. Mahakalkar, S.M.; Nagrale, D.; Gaur, S.; Urade, C.; Murhar, B.; Turankar, A. N-acetylcysteine as an add-on to directly observed therapy short-I therapy in fresh pulmonary tuberculosis patients: A randomized, placebo-controlled, double-blinded study. Perspect. Clin. Res. 2017, 8, 132. [CrossRef] [PubMed]

99. Memorial Sloan Kettering Cancer Center. A study of N-Acetylcysteine in Patients with COVID-19 Infection (2020). Available online: https: / / clinicaltrials.gov/ct2/show/NCT04374461 (accessed on 5 April 2021).

100. Wiest, D.B.; Chang, E.; Fanning, D.; Garner, S.; Cox, T.; Jenkins, D.D. Antenatal pharmacokinetics and placental transfer of $\mathrm{N}$-acetylcysteine in chorioamnionitis for fetal neuroprotection. J. Pediatr. 2014, 165, 672-677. [CrossRef] [PubMed]

101. Buhimschi, C.S.; Bahtiyar, M.O.; Zhao, G.; Abdelghany, O.; Schneider, L.; Razeq, S.A.; Dulay, A.T.; Lipkind, H.S.; Mieth, S.; Rogers, L.; et al. Antenatal N-acetylcysteine to improve outcomes of premature infants with intra-amniotic infection and inflammation (Triple I): Randomized clinical trial. Pediatr. Res. 2021, 89, 175-184. [CrossRef] [PubMed]

102. Allameh, Z.; Karimi, A.; Rafiei Tabatabaei, S.; Sharifian, M.; Salamzadeh, J. Effect of N-acetylcysteine on inflammation biomarkers in pediatric acute pyelonephritis: A randomized controlled trial. Iran. J. Kidney Dis. 2015, 9, 454-462.

103. Won, H.R.; Lee, G.H.; Kim, J.H.; Lee, S.H.; Kwon, S.Y.; Baek, S.K.; Ryu, C.H.; Lee, S.J.; Park, I.S.; Shin, S.C.; et al. Effects of $\mathrm{N}$-acetylcysteine inhalation therapy on the quality of life of patients with head and neck cancer who are receiving radiation therapy: A prospective non-randomized controlled multi-center study. J. Cancer Res. Clin. Oncol. 2020, 147, 539-547. [CrossRef]

104. Sio, T.T.; Blanchard, M.J.; Novotny, P.J.; Patel, S.H.; Rwigema, J.C.M.; Pederson, L.D.; McGee, L.A.; Gamez, M.E.; Seeger, G.R.; Manterson, J.A.; et al. N-acetylcysteine rinse for thick secretion and mucositis of head and neck chemoradiotherapy (Alliance MC13C2): A double-blind randomized clinical trial. In Mayo Clinic Proceedings; Elsevier: Amsterdam, The Netherlands, 2019; Volume 94, pp. 1814-1824. [CrossRef]

105. Machado, R.C.B.R.; Vargas, H.O.; Urbano, M.R.; Verri, W.A., Jr.; Porcu, M.; Nunes, S.O.V. N-acetylcysteine as an adjunctive treatment for smoking cessation: A randomized clinical trial. Braz. J. Psychiatry 2020, 42, 519-526. [CrossRef]

106. Jannatifar, R.; Parivar, K.; Roodbari, N.H.; Nasr-Esfahani, M.H. Effects of N-acetyl-cysteine supplementation on sperm quality, chromatin integrity and level of oxidative stress in infertile men. Reprod. Biol. Endocrinol. 2019, 17, 24. [CrossRef]

107. Nur, E.; Brandjes, D.P.; Teerlink, T.; Otten, H.M.; Oude Elferink, R.P.J.; Muskiet, F.; Evers, L.M.; ten Cate, H.; Biemond, B.J.; Duits, A.J.; et al. N-acetylcysteine reduces oxidative stress in sickle cell patients. Ann. Hematol. 2012, 91, 1097-1105. [CrossRef] 
108. Pace, B.S.; Shartava, A.; Pack-Mabien, A.; Mulekar, M.; Ardia, A.; Goodman, S.R. Effects of N-acetylcysteine on dense cell formation in sickle cell disease. Am. J. Hematol. 2003, 73, 26-32. [CrossRef]

109. Motawei, S.M.; Attalla, S.M.; Gouda, H.E.; Harouny, M.A.; Elmansoury, A.M. The effects of N-acetyl cysteine on oxidative stress among patients with pre-eclampsia. Int. J. Gynecol Obstet. 2016, 135, 226-227. [CrossRef]

110. Roes, E.M.; Raijmakers, M.T.; De Boo, T.M.; Zusterzeel, P.L.; Merkus, H.M.; Peters, W.H.; Steegers, E.A. Oral N-acetylcysteine administration does not stabilise the process of established severe preeclampsia. Eur. J. Obs. Gynecol. Reprod. Biol. 2006, 127, 61-67. [CrossRef] [PubMed]

111. Rani, M.; Aggarwal, R.; Vohra, K. Effect of N-Acetylcysteine on metabolic profile in metabolic syndrome patients. Metab. Synd. Relat. Disord. 2020, 18341-18346. [CrossRef]

112. Yalçin, E.; Feyza, A.; Feriha, C.; Okan, A.M. N-acetylcysteine in chronic blepharitis. Cornea 2002, 21, 164-168. [CrossRef] [PubMed]

113. Akyol-Salman, I.; Azizi, S.; Mumcu, U.; Baykal, O. Efficacy of topical N-acetylcysteine in the treatment of meibomian gland dysfunction. J. Ocul. Pharmacol. Ther. 2010, 26, 329-333. [CrossRef]

114. Akyol-Salman, I.; Azizi, S.; Mumcu, U.; Baykal, O. Comparison of the efficacy of topical N-acetyl-cysteine and a topical steroidantibiotic combination therapy in the treatment of meibomian gland dysfunction. J. Ocul. Pharmacol. Ther. 2012, $28,49-52$. [CrossRef] [PubMed]

115. Rabe, K.F.; Watz, H. Chronic obstructive pulmonary disease. Lancet 2017, 389, 1931-1940. [CrossRef]

116. Santus, P.; Corsico, A.; Solidoro, P.; Braido, F.; Di Marco, F.; Scichilone, N. Oxidative stress and respiratory system: Pharmacological and clinical reappraisal of N-Acetylcysteine. COPD 2014, 11, 705-717. [CrossRef]

117. Sadowska, A.M.; Manuel-Y-Keenoy, B.; De Backer, W.A. Antioxidant and anti-inflammatory efficacy of NAC in the treatment of COPD: Discordant in vitro and in vivo dose-effects: A review. Pulm. Pharm. Ther. 2007, 20, 9-22. [CrossRef]

118. Cazzola, M.; Rogliani, P.; Calzetta, L.; Hanania, N.A.; Matera, M.G. Impact of mucolytic agents on COPD exacerbations: A pair-wise and Network meta-analysis. COPD J. Chronic Obstr. Pulm. Dis. 2017, 14, 552-563. [CrossRef] [PubMed]

119. Global Initiative for Chronic Obstructive Lung Disease (GOLD). Global Strategy for the Diagnosis, Management, and Prevention of Chronic Obstructive Pulmonary Disease. 2021. Available online: https://goldcopd.org/wp-content/uploads/2020/11/ GOLD-REPORT-2021-v1.1-25Nov20_WMV.pdf (accessed on 2 April 2021).

120. Cantu-Gonzalez, G. 50 years ago in The Journal of Pediatrics: The use of N-acetylcysteine in the treatment of cystic fibrosis. J. Pediatr. 2014, 165, 721. [CrossRef]

121. Tam, J.; Nash, E.F.; Ratjen, F.; Tullis, E.; Stephenson, A. Nebulized and oral thiol derivatives for pulmonary disease in cystic fibrosis. Cochrane Database Syst. Rev. 2013, 7, CD007168. [CrossRef] [PubMed]

122. Nash, E.F.; Stephenson, A.; Ratjen, F.; Tullis, E. Nebulized and oral thiol derivatives for pulmonary disease in cystic fibrosis. Cochrane Database Syst Rev. 2009, 1, CD007168. [CrossRef]

123. Sun, T.; Liu, J.; Zhao, D.W. Efficacy of N-Acetylcysteine in idiopathic pulmonary fibrosis: A systematic review and meta-analysis. Medicine 2016, 95, e3629. [CrossRef] [PubMed]

124. Liu, Y.M.; Nepali, K.; Liou, J.P. Idiopathic pulmonary fibrosis: Current status, recent progress, and emerging targets. J. Med. Chem. 2016, 60, 527-553. [CrossRef]

125. Paliogiannis, P.; Fois, A.G.; Collu, C.; Bandinu, A.; Zinellu, E.; Carru, C.; Pirina, P.; Mangoni, A.A.; Zinellu, A. Oxidative stress-linked biomarkers in idiopathic pulmonary fibrosis: A systematic review and meta-analysis. Biomark. Med. 2018, 12, 1175-1184. [CrossRef]

126. Cantin, A.M.; Hubbard, R.C.; Crystal, R.G. Glutathione deficiency in the epithelial lining fluid of the lower respiratory tract in idiopathic pulmonary fibrosis. Am. Rev. Respir. Dis. 1989, 139, 370-372. [CrossRef]

127. Sochman, J. N-acetylcysteine in acute cardiology: 10 years later: What do we know and what would we like to know? J. Am. Coll. Cardiol. 2002, 39, 1422-1428. [CrossRef]

128. Pasupathy, S.; Tavella, R.; Grover, S.; Raman, B.; Procter, N.E.K.; Du, Y.T.; Mahadavan, G.; Stafford, I.; Heresztyn, T.; Holmes, A.; et al. Early use of n-acetylcysteine with nitrate therapy in patients undergoing primary percutaneous coronary intervention for st-segment-elevation myocardial infarction reduces myocardial infarct size (the NACIAM Trial [N-acetylcysteine in Acute Myocardial Infarction]). Circulation 2017, 136, 894-903. [CrossRef]

129. Horowitz, J.D.; Henry, C.A.; Syrjanen, M.L.; Louis, W.J.; Fish, R.D.; Smith, T.W.; Antman, E.M. Combined use of nitroglycerin and $\mathrm{N}$-acetylcysteine in the management of unstable angina pectoris. Circulation 1988, 77, 787-794. [CrossRef] [PubMed]

130. McColl, A.J.; Keeble, T.; Hadjinikolaou, L.; Cohen, A.; Aitkenhead, H.; Glenville, B.; Richmond, W. Plasma antioxidants: Evidence for a protective role against reactive oxygen species following cardiac surgery. Ann. Clin Biochem. 1998, 35, 616-623. [CrossRef] [PubMed]

131. Sucu, N.; Cinel, I.; Unlu, A.; Aytacoglu, B.; Tamer, L.; Kocak, Z.; Karaca, K.; Gul, A.; Dikmengil, M.; Atik, U.; et al. N-acetylcysteine for preventing pump-induced oxide inflammatory response during cardiopulmonary bypass. Surg. Today 2004, 34, $237-242$. [CrossRef]

132. Cacciapuoti, F. N-Acetyl-Cysteine supplementation lowers high homocysteine plasma levels and increases Glutathione synthesis in the trans-sulfuration pathway. Ital. J. Med. 2019, 13, 234-240. [CrossRef]

133. Baker, W.L.; Anglade, M.W.; Baker, E.L.; White, C.M.; Kluger, J.; Coleman, C.I. Use of N-acetylcysteine to reduce postcardiothoracic surgery complications: A meta-analysis. Eur. J. Cardiothorac. Surg. 2009, 35, 521-527. [CrossRef] [PubMed] 
134. Dean, O.; Giorlando, F.; Berk, M. N-acetylcysteine in psychiatry: Current therapeutic evidence and potential mechanisms of action. J. Psychiatry Neurosci. 2011, 36, 78-86. [CrossRef] [PubMed]

135. Kim, Y.; Vadodaria, K.C.; Lenkei, Z.; Kato, T.; Gage, F.H.; Marchetto, M.C.; Santos, R. Mitochondria, metabolism, and redox mechanisms in psychiatric disorders. Antioxid. Redox Signal. 2019, 31, 275-317. [CrossRef]

136. Farokhnia, M.; Azarkolah, A.; Adinehfar, F.; Khodaie-Ardakani, M.R.; Hosseini, S.M.R.; Yekehtaz, H.; Tabrizi, M.; Rezaei, F.; Salehi, B.; Sadeghi, S.M.R.; et al. N-acetylcysteine as an adjunct to risperidone for treatment of negative symptoms in patients with chronic schizophrenia: A randomized, double-blind, placebo-controlled study. Clin. Neuropharmacol. 2013, 36, 185-192. [CrossRef] [PubMed]

137. Lavoie, S.; Murray, M.M.; Deppen, P.; Knyazeva, M.G.; Berk, M.; Boulat, O.; Bovet, P.; Bush, A.I.; Conus, P.; Copolov, D.; et al. Glutathione precursor, N-acetyl-cysteine, improves mismatch negativity in schizophrenia patients. Neuropsychopharmacology 2008, 33, 2187-2199. [CrossRef]

138. Retsa, C.; Knebel, J.F.; Geiser, E.; Ferrari, C.; Jenni, R.; Fournier, M.; Alameda, L.; Baumann, P.S.; Clarke, S.; Conus, P.; et al. Treatment in early psychosis with $\mathrm{N}$-acetyl-cysteine for 6 months improves low-level auditory processing: Pilot study. Schizophr. Res. 2018, 191, 80-86. [CrossRef]

139. Carmeli, C.; Knyazeva, M.G.; Cuénod, M.; Do, K.Q. Glutathione precursor N-acetyl-cysteine modulates EEG synchronization in schizophrenia patients: A double-blind, randomized, placebo-controlled trial. PLoS ONE 2012, 7, e29341. [CrossRef]

140. McQueen, G.; Lally, J.; Collier, T.; Zelaya, F.; Lythgoe, D.; Barker, G.J.; Stone, J.M.; McGuire, P.; MacCabe, J.H.; Egerton, A. Effects of $\mathrm{N}$-acetylcysteine on brain glutamate levels and resting perfusion in schizophrenia. Psychopharmacology 2018, 235, 3045-3054. [CrossRef]

141. Moghaddam, B.; Javitt, D. From revolution to evolution: The glutamate hypothesis of schizophrenia and its implication for treatment. Neuropsychopharmacology 2012, 37, 4-15. [CrossRef]

142. Willborn, R.J.; Hall, C.P.; Fuller, M.A. Recycling N-acetylcysteine: A review of evidence for adjunctive therapy in schizophrenia. Ment. Health Clin. 2019, 9, 116-123. [CrossRef]

143. Matsuzawa, D.; Hashimoto, K. Magnetic resonance spectroscopy study of the antioxidant defense system in schizophrenia. Antioxid. Redox Signal. 2011, 15, 2057-2065. [CrossRef] [PubMed]

144. Yang, C.; Bosker, F.J.; Li, J.; Schoevers, R.A. N-acetylcysteine as add-on to antidepressant medication in therapy refractory major depressive disorder patients with increased inflammatory activity: Study protocol of a double-blind randomized placebocontrolled trial. BMC Psychiatry 2018, 18, 279. [CrossRef] [PubMed]

145. Slattery, J.; Kumar, N.; Delhey, L.; Berk, M.; Dean, O.; Spielholz, C.; Frye, R. Clinical trials of N-acetylcysteine in psychiatry and neurology: A systematic review. Neurosci. Biobehav. Rev. 2015, 55, 294-321. [CrossRef]

146. Paoletti, P. Molecular basis of NMDA receptor functional diversity. Eur. J. Neurosci. 2011, 33, 1351-1365. [CrossRef]

147. De Farias, C.C.; Maes, M.; Bonifácio, K.L.; Bortolasci, C.C.; Nogueira, A.S.; Brinholi, F.F.; Matsumoto, A.K.; do Nascimento, M.A.; Melo, L.B.; Nixdorf, S.L.; et al. Highly specific changes in antioxidant levels and lipid peroxidation in Parkinson's disease and its progression: Disease and staging biomarkers and new drug targets. Neurosci. Lett. 2016, 617, 66-71. [CrossRef]

148. Percário, S.; Barbosa, A.S.; Varela, E.L.P.; Gomes, A.R.Q.; Ferreira, M.E.S.; Moreira, T.N.A.; Dolabela, M.F. Oxidative stress in Parkinson's disease: Potential benefits of antioxidant supplementation. Oxidative Med. Cell. Longev. 2020, 2020, 1-23. [CrossRef] [PubMed]

149. Hara, Y.; McKeehan, N.; Dacks, P.A.; Fillit, H.M. Evaluation of the neuroprotective potential of n-acetylcysteine for prevention and treatment of cognitive aging and dementia. J. Prev. Alzheimer's Dis. 2017, 4, 201-206. [CrossRef]

150. Choi, I.Y.; Lee, S.P.; Denney, D.R.; Lynch, S.G. Lower levels of glutathione in the brains of secondary progressive multiple sclerosis patients measured by $1 \mathrm{H}$ magnetic resonance chemical shift imaging at 3 T. Mult. Scler. 2011, 17, 289-296. [CrossRef]

151. Goldenberg, M.M. Multiple sclerosis review. Pharm. Ther. 2012, 37, 175-184.

152. Ibitoye, R.; Kemp, K.; Rice, C.; Hares, K.; Scolding, N.; Wilkins, A. Oxidative stress-related biomarkers in multiple sclerosis: A review. Biomark. Med. 2016, 10, 889-902. [CrossRef] [PubMed]

153. Plemel, J.R.; Juzwik, C.A.; Benson, C.A.; Monks, M.; Harris, C.; Ploughman, M. Over-the-counter anti-oxidant therapies for use in multiple sclerosis: A systematic review. MS J. 2015, 21, 1485-1495. [CrossRef] [PubMed]

154. Asrani, S.K.; Devarbhavi, H.; Eaton, J.; Kamath, P.S. Burden of liver diseases in the world. J. Hepatol. 2019, 70, 151-171. [CrossRef]

155. Cichoż-Lach, H.; Michalak, A. Oxidative stress as a crucial factor in liver diseases. World J. Gastroenterol. 2014, 20 , 8082-8091. [CrossRef]

156. Harrison, P.M.; Wendon, J.A.; Gimson, A.E.; Alexander, G.J.; Williams, R. Improvement by acetylcysteine of hemodynamics and oxygen transport in fulminant hepatic failure. N. Engl. J. Med. 1991, 324, 1852-1857. [CrossRef]

157. Darweesh, S.K.; Ibrahim, M.F.; El-Tahawy, M.A. Effect of N-Acetylcysteine on mortality and liver transplantation rate in non-acetaminophen-induced acute liver failure: A multicenter study. Clin. Drug Investig. 2017, 37, 473-482. [CrossRef] [PubMed]

158. Walayat, S.; Shoaib, H.; Asghar, M.; Kim, M.; Dhillon, S. Role of N-acetylcysteine in non-acetaminophen-related acute liver failure: An updated meta-analysis and systematic review. Ann. Gastroenterol. 2021, 34, 235-240. [CrossRef]

159. Dludla, P.V.; Nkambule, B.B.; Mazibuko-Mbeje, S.E.; Nyambuya, T.M.; Marcheggiani, F.; Cirilli, I.; Ziqubu, K.; Shabalala, S.C.; Johnson, R.; Louw, J.; et al. N-Acetyl cysteine targets hepatic lipid accumulation to curb oxidative stress and inflammation in NAFLD: A comprehensive analysis of the literature. Antioxidants 2020, 9, 1283. [CrossRef] [PubMed] 
160. Ayhan, B.; Pamuk, G.; Kantar, B.; Kanbak, M.; Celebioglu, B.; Aypar, U. Renal functional effects of using N-acetylcysteine in cardiac surgery. Anesth. J. 2012, 20, 159-167.

161. Santana-Santos, E.; Gowdak, L.H.; Gaiotto, F.A.; Puig, L.B.; Hajjar, L.A.; Zeferino, S.P.; Drager, L.F.; Shimizu, M.H.M.; Bortolotto, L.A.; De Lima, J.J.G. High dose of N-acetylcysteine prevents acute kidney injury in chronic kidney disease patients undergoing myocardial revascularization. Ann. Thorac. Surg. 2014, 97, 1617-1623. [CrossRef]

162. Mei, M.; Zhao, H.W.; Pan, Q.G.; Pu, Y.M.; Tang, M.Z.; Shen, B.B. Efficacy of N-acetylcysteine in preventing acute kidney injury after cardiac surgery: A meta-analysis study. J. Investig. Surg. 2018, 31, 14-23. [CrossRef]

163. Leja, M.; Grinberga-Derica, I.; Bilgilier, C.; Steininger, C. Review: Epidemiology of Helicobacter pylori infection. Helicobacter 2019, 24, e12635. [CrossRef]

164. Kotilea, K.; Bontems, P.; Touati, E. Epidemiology, diagnosis and risk factors of Helicobacter pylori infection. Helicobacter Pylori Hum. Dis. 2019, 1149, 17-33. [CrossRef]

165. De Brito, B.B.; Da Silva, F.A.F.; Soares, A.S.; Pereira, V.A.; Santos, M.L.C.; Sampaio, M.M.; Neves, P.H.M.; De Melo, F.F. Pathogenesis and clinical management of Helicobacter pylori gastric infection. World J. Gastroenterol. 2019, 25, 5578. [CrossRef] [PubMed]

166. Chey, W.D.; Leontiadis, G.; Howden, C.W.; Moss, S.F. ACG clinical guideline: Treatment of Helicobacter pylori infection. Am. J. Gastroenterol. 2017, 112, 212-239. [CrossRef] [PubMed]

167. Malfertheiner, P.; Megraud, F.; O’Morain, C.A.; Gisbert, J.P.; Kuipers, E.J.; Axon, A.T.; Bazzoli, F.; Gasbarrini, A.; Atherton, J.; Graham, D.Y.; et al. Management of Helicobacter pylori infection-The Maastricht V/Florence consensus report. Gut 2017, 66, 6-30. [CrossRef] [PubMed]

168. Choi, I.J.; Kook, M.C.; Kim, Y.I.; Cho, S.J.; Lee, J.Y.; Kim, C.G.; Park, B.; Nam, B.H. Helicobacter pylori therapy for the prevention of metachronous gastric cancer. N. Engl. J. Med. 2018, 378, 1085-1095. [CrossRef]

169. Makipour, K.; Friedenberg, F.K. The potential role of N-acetylcysteine for the treatment of Helicobacter pylori. J. Clin. Gastroenterol. 2011, 45, 841-843. [CrossRef] [PubMed]

170. Xie, C.; Yi, J.; Nie, M.; Huang, M.; Rong, J.; Zhu, Z.; Chen, J.; Zhou, X.; Li, B.; Chen, H.; et al. N-acetylcysteine reduces ROS-mediated oxidative DNA damage and PI3K/Akt pathway activation induced by helicobacter pylori infection. Oxidative Med. Cell. Longev. 2018, 2018, 1-9. [CrossRef] [PubMed]

171. Jang, S.; Bak, E.J.; Cha, J.H. N-acetylcysteine prevents the development of gastritis induced by Helicobacter pylori infection. J. Microbiol. 2017, 55, 396-402. [CrossRef]

172. Fontes, L.E.S.; Martimbianco, A.L.C.; Zanin, C.; Riera, R. N-acetylcysteine as an adjuvant therapy for Helicobacter pylori eradication. Cochrane Database Syst. Rev. 2019, 2, 1-71. [CrossRef]

173. Chen, C.C.; Luo, J.C.; Fang, Y.J.; Lee, J.Y.; Kuo, C.C.; Yang, T.H.; Chiu, M.C.; Yu, J.J.; Bair, M.J.; Chen, P.Y.; et al. Comparison of the effect of clarithromycin triple therapy with or without $\mathrm{N}$-acetylcysteine in the eradication of Helicobacter pylori: A randomized controlled trial. Ther. Adv. Gastroenterol. 2020, 13, 1756284820927306. [CrossRef]

174. Romagnoli, C.; Marcucci, T.; Picariello, L.; Tonelli, F.; Vincenzini, M.T.; Iantomasi, T. Role of N-acetylcysteine and GSH redox system on total and active MMP-2 in intestinal myofibroblasts of Crohn's disease patients. Int. J. Colorectal Dis. 2013, 28, 915-924. [CrossRef]

175. Fontani, F.; Marcucci, T.; Picariello, L.; Tonelli, F.; Vincenzini, M.T.; Iantomasi, T. Redox regulation of MMP-3/TIMP-1 ratio in intestinal myofibroblasts: Effect of N-acetylcysteine and curcumin. Exp. Cell Res. 2014, 323, 77-86. [CrossRef]

176. Schauble, A.L.; Bisaccia, E.K.; Lee, G.; Nasr, S.Z. N-acetylcysteine for management of distal intestinal obstruction syndrome. J. Pediatric Pharmacol. Ther. 2019, 24, 390-397. [CrossRef]

177. Chilvers, N.J.S.; Wheeler, J. Intraoperative intraluminal injection of N-acetylcysteine allowing treatment of distal intestinal obstruction syndrome without the need for enterotomy. Case Rep. 2018, 2018, bcr-2017. [CrossRef]

178. Mccarty, M.F.; Lerner, A. Perspective: Prospects for nutraceutical support of intestinal barrier function. Adv. Nutr. 2021, 12, 316-324. [CrossRef]

179. Koch, A.; Trautwein, C. N-acetylcysteine on its way to a broader application in patients with acute liver failure. Hepatology 2010, 51, 338-340. [CrossRef]

180. Amaral, E.P.; Conceição, E.L.; Costa, D.L.; Rocha, M.S.; Marinho, J.M.; Cordeiro-Santos, M.; D’Império-Lima, M.R.; Barbosa, T.; Sher, A.; Andrade, B.B. N-acetyl-cysteine exhibits potent anti-mycobacterial activity in addition to its known anti-oxidative functions. BMC Microbiol. 2016, 16, 1-10. [CrossRef]

181. Jorge-Aarón, R.M.; Rosa-Ester, M.P. N-acetylcysteine as a potential treatment for novel coronavirus disease 2019. Future Microbiol. 2020, 15, 959-962. [CrossRef]

182. De Flora, S.; Balansky, R.; La Maestra, S. Rationale for the use of N-acetylcysteine in both prevention and adjuvant therapy of COVID-19. FASEB J. 2020, 34, 13185-13193. [CrossRef]

183. Poe, F.L.; Corn, J. N-Acetylcysteine: A potential therapeutic agent for SARS-CoV-2. Med. Hypotheses 2020, 143, 109862. [CrossRef] [PubMed]

184. Rahimi, A.; Samimagham, H.R.; Azad, M.H.; Hooshyar, D.; Arabi, M.; KazemiJahromi, M. The efficacy of N-Acetylcysteine in severe COVID-19 patients: A structured summary of a study protocol for a randomised controlled trial. Trials 2021, 22, 271. [CrossRef] 
185. Jenkins, D.D.; Wiest, D.B.; Mulvihill, D.M.; Hlavacek, A.M.; Majstoravich, S.J.; Brown, T.R.; Taylor, J.J.; Buckley, J.R.; Turner, R.P.; Rollins, L.G.; et al. Fetal and neonatal effects of n-acetylcysteine when used for neuroprotection in maternal chorioamnionitis. J. Pediatr. 2016, 168, 67-76. [CrossRef]

186. Martinez-Outschoorn, U.E.; Peiris-Pages, M.; Pestell, R.G.; Sotgia, F.; Lisanti, M.P. Cancer metabolism: A therapeutic perspective. Nat. Rev. Clin. Oncol. 2016, 14, 11-31. [CrossRef]

187. Wallace, D.C. Mitochondria and cancer. Nat. Rev. Cancer 2012, 12, 685-698. [CrossRef] [PubMed]

188. Romero, I.L.; Mukherjee, A.; Kenny, H.A.; Litchfield, L.M.; Lengyel, E. Molecular pathways: Trafficking of metabolic resources in the tumor microenvironment. Clin. Cancer Res. 2015, 21, 680-686. [CrossRef]

189. Yoo, J.; Hamilton, S.; Angel, D.; Fung, K.; Franklin, J.; Parnes, L.S.; Lewis, D.; Venkatesan, V.; Winquist, E. Cisplatin otoprotection using transtympanic L-N-acetylcysteine: A pilot randomized study in head and neck cancer patients. Laryngoscope 2014, 124, E87-E94. [CrossRef]

190. Monti, D.; Sotgia, F.; Whitaker-Menezes, D.; Tuluc, M.; Birbe, R.; Berger, A.; Lazar, M.; Cotzia, P.; Draganova-Tacheva, R.; Lin, Z.; et al. Pilot study demonstrating metabolic and anti-proliferative effects of in vivo antioxidant supplementation with N-Acetylcysteine in breast cancer. Semin Oncol. 2017, 44, 226-232. [CrossRef] [PubMed]

191. Manfredi, G.; Bertè, R.; Iiritano, S.; Londoni, C.; Brambilla, G.; Romeo, S.; Menozzi, F.; Griffanti, P.; Brandi, G.; Moreschi, O.; et al. Premedication with simethicone and $\mathrm{N}$-acetylcysteine for improving mucosal visibility during upper gastrointestinal endoscopy in a Western population. Endosc. Int. Open 2021, 9, E190-E194. [CrossRef]

192. Zhang, L.; Cheng, J.; Ji, M.; Wu, S.; Zhai, H.; Zhang, S. IDDF2019-ABS-0311 Efficacy and cost-effectiveness of premedication with $\mathrm{N}$-acetylcysteine during upper gastrointestinal endoscopy examination: A single center, prospective, single blinded, randomized controlled trial. Gut 2019, 68, A117-A118.

193. Lee, Y.J.; Lee, D.M.; Lee, C.H.; Heo, S.H.; Won, S.Y.; Im, J.H.; Cho, M.K.; Nam, H.S.; Lee, S.H. Suppression of human prostate cancer PC-3 cell growth by N-acetylcysteine involves over-expression of Cyr61. Toxicol. Vitro 2011, 25, 199-205. [CrossRef]

194. Deng, J.; Liu, A.D.; Hou, G.Q.; Zhang, X.; Ren, K.; Chen, X.Z.; Li, S.S.C.; Wu, Y.S.; Cao, X. N-acetylcysteine decreases malignant characteristics of glioblastoma cells by inhibiting Notch2 signaling. J. Exp. Clin. Cancer Res. 2019, 38, 1-15. [CrossRef]

195. Adil, M.; Amin, S.S.; Mohtashim, M. N-acetylcysteine in dermatology. Indian J. Dermatol. Venereol. Leprol. 2018, 84, 652-659. [CrossRef]

196. Lee, T.M.; Lee, K.M.; Lee, C.Y.; Lee, H.C.; Tam, K.W.; Loh, E.W. Effectiveness of N-acetylcysteine in autism spectrum disorders: A meta-analysis of randomized controlled trials. Aust. N. Z. J. Psychiatr. 2021, 55, 196-206. [CrossRef] [PubMed]

197. Ghafarizadeh, A.; Malmir, M.; Noreini, S.N.; Faraji, T. Antioxidant effects of N-acetylcysteine on the male reproductive system: A systematic review. Andrologia 2021, 53, e13898. [CrossRef] [PubMed]

198. Sins, J.W.R.; Fijnvandraat, K.; Rijneveld, A.W.; Boom, M.B.; Kerkhoffs, J.L.; van Meurs, A.H.; De Groot, M.R.; Heijboer, H.; Dresse, M.F.; Ferster, A.; et al. N-Acetylcysteine in patients with sickle cell disease: A randomized controlled trial. Blood 2016, 128. [CrossRef]

199. Moazzen, H.; Lu, X.; Ma, N.L.; Velenosi, T.J.; Urquhart, B.L.; Wisse, L.J.; Gittenberger-de Groot, A.C.; Feng, Q. N-Acetylcysteine prevents congenital heart defects induced by pregestational diabetes. Cardiovasc. Diabetol. 2014, 13, 46. [CrossRef]

200. Braun, T.L.; Patel, V.; DeBord, L.C.; Rosen, T. A review of N-acetylcysteine in the treatment of grooming disorders. Int. J. Dermatol. 2019, 58, 502-510. [CrossRef]

201. Pokupec, R.; Petricek, I.; Bradic, M.; Popovic-Suic, S.; Petricek, G. Comparison of local acetylcysteine and artificial tears in the management of dry eye syndrome. Acta Med. Croat. 2005, 59, 337-340. 